F128.64 .N4N4

1936

c. 2

\title{
THE NEW YORK STATE
}

\section{THEODORE ROOSEVELT MEMORIAL}

DEDICATED : JANUARY 19, 1936 
LIBRARY OF THE

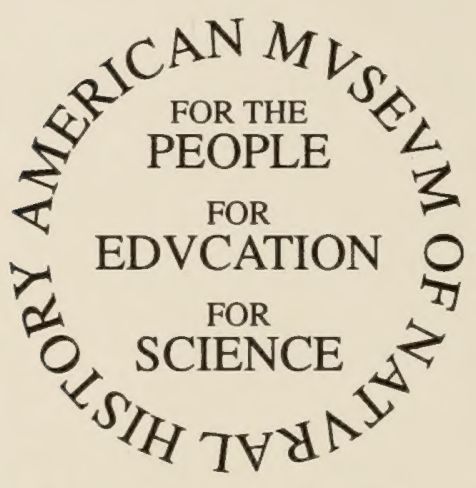


Compliments of the

\section{Trustees of the New York State \\ Theodore Roosevelt Memorial}

Seventy-Ninth Street and Central Park West

New York City 



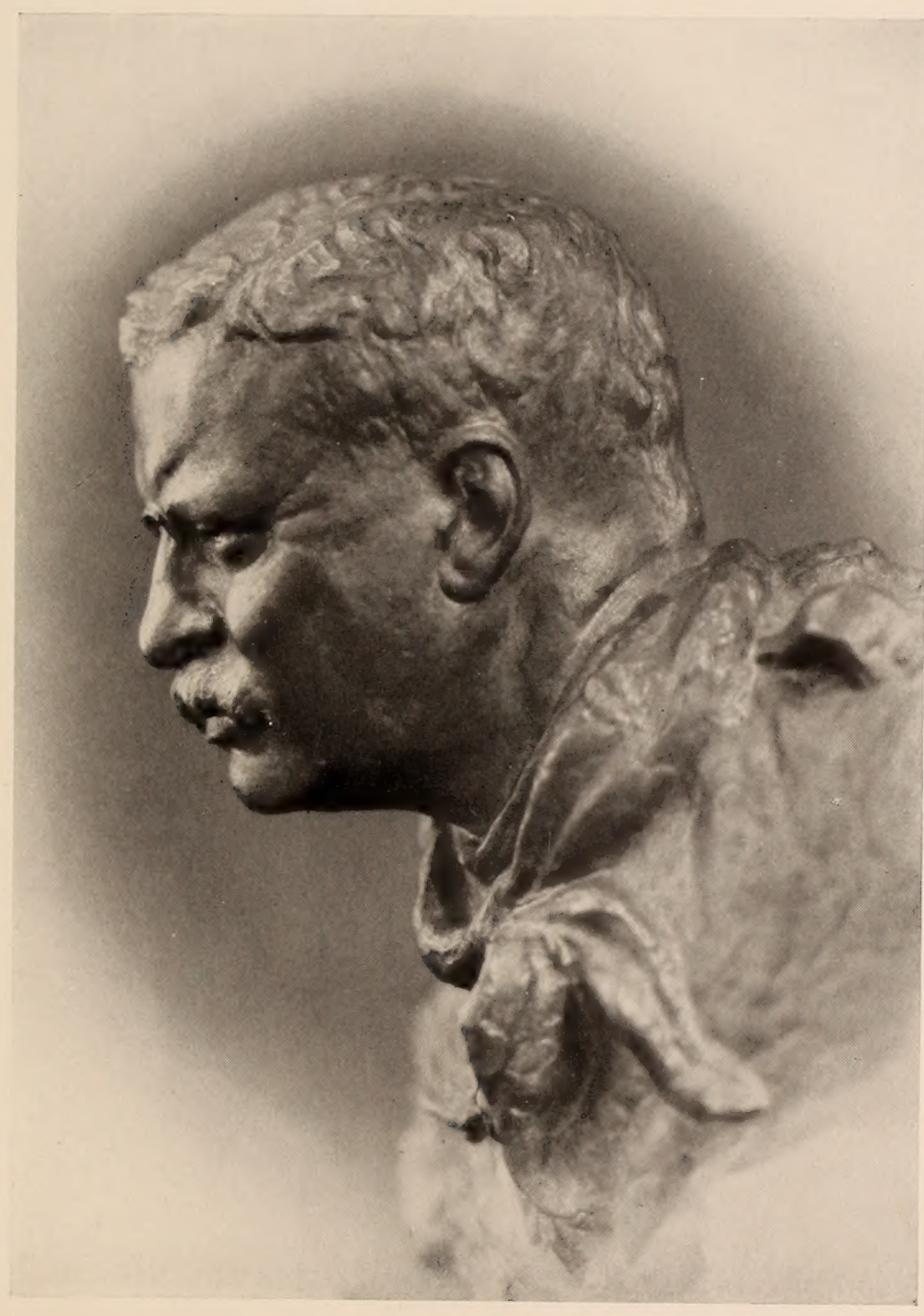

"THE SENATE BUST"

By James E. Fraser

A portrait that will always live

THEODORE ROOSEVELT

Born: October 27, 1858

Died: January 6, 1919

"Time like an ever-rolling stream bears all its sons away." 



\title{
The New York State \\ Theodore Roosevelt Memorial
}

\author{
Dedicated
}

JANUARY NINETEEN

NINETEEN THIRTY-SIX

Prepared under the Direction of

THE BOARD OF TRUSTEES

By

George N. Pindar, Secretary 
With something of the savant and the sage,

He was, when all is said and sung, a man;

The flower imperishable of this valiant age,

A True American

-Clinton Scollard 
"Welding into one dynamic personality the rare qualities of aristocracy of both education and training with an all-pervading democracy of both thought and action, uniting the ripe judgment of the scholar and philosopher with the keen foresight of the visionary; firm and unyielding to the point of hardness, yet cloaking refusal and rebuke with such evident and overwhelming love for his fellows that they made friends instead of enemies; of indomitable will, unconquerable courage and a power of mental and physical endurance that yielded only to his Maker's demand, Theodore Roosevelt stands preeminently the most lovable, the most versatile, the greatest representative of a great and versatile people.

"In his death America has lost a great statesman, a soldier who could either command or obey, an unassuming philanthropist, an undaunted explorer; a beloved leader and wise counsellor and withal an unadulterated American - a man among men."

(Joint Resolution Adopted by the Legislature of the State of New York, January 8, 1919.) 



\section{BOARD OF TRUSTEES}

THE GOVERNOR

$$
\text { Ex-officio }
$$

HENRY FAIRFIELD OSBORN, deceased

Chairman

PETER D. KIERNAN

Vice-Chairman

ETHEL ROOSEVELT DERBY

CHARLES W. FLINT

ALICE CAMPBELL GOOD

CHAUNCEY J. HAMLIN

FELIX M. WARBURG

CORINNE ROOSEVELT ROBINSON, deceased

GEORGE N. PINDAR

Secretary

Architecture

JOHN RUSSELL POPE

Murals

WILLIAM ANDREW MACKAY

Bas-reliefs

EDWIN F. SANFORD, JR.

Superintendent of Public Works

FREDERICK STUART GREENE

Chief Engineer

THOMAS F. FARRELL

State Architect

WILLIAM E. HAUGAARD

Sculpture

JAMES EARLE FRASER 



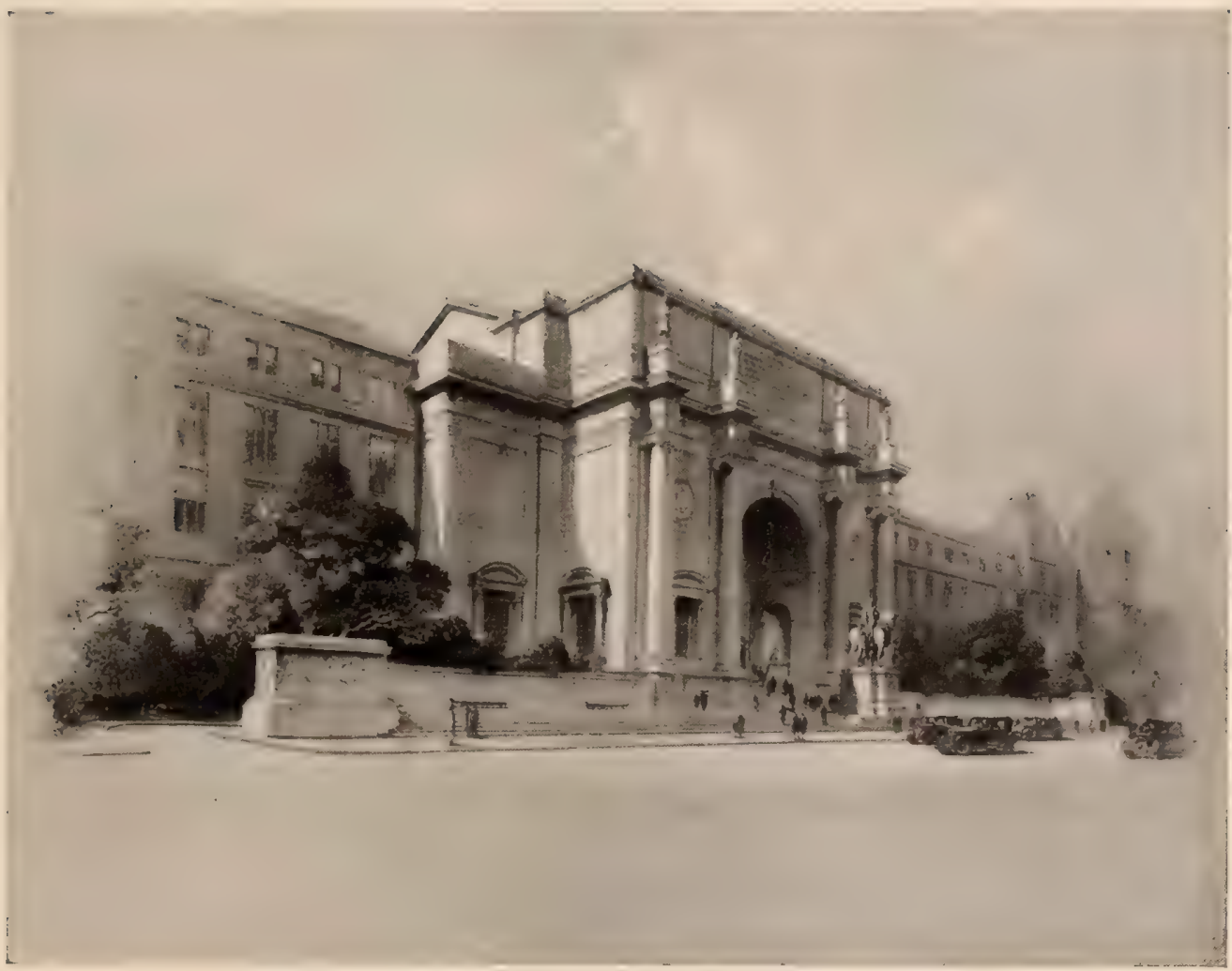

ENTRANCE TO THE THEODORE ROOSEVELT MEMIORIAL

Facing Central Park West, at the intersection of Seventy-ninth Street, New York City 



\section{THE THEODORE ROOSEVELT MEMORIAL}

Erected by the State of New York in Memory of a Great Naturalist and Statesman

$\mathrm{N}$ the axis of Seventy-ninth Street and Central Park West, in the city of New York, there has been erected a building by the people of the State of New York which, in the hearts of Americans, always will be associated intimately with the man it memorializes. The corner stone of this building, which is known as the New York State Roosevelt Memorial, was laid with appropriate ceremonies on October 27, 1931, by Franklin D. Roosevelt, Governor of the State of New York, and dedicated by him as President of the United States on January 19, 1936.

In 1920 the Legislature of New York created a Commission to investigate and report on a proposed Roosevelt Memorial which would for all time stand as a visible recognition of the services of one who had been most active in the welfare and development of our State and Nation.

In planning the Memorial, three factors were considered:

First, to interpret the character of Roosevelt as naturalist and as citizen. John Burroughs wrote of him with an understanding acquired through close association and kindred tastes:

"Such unbounded energy and vitality impressed one like the perennial forces of nature. . . . He was a naturalist on the broadest grounds, uniting much technical knowledge with knowledge of the daily lives and habits 


\section{THEODORE ROOSEVELT MEMORIAL}

of all forms of wild life. He probably knew tenfold more natural history than all the presidents who preceded him, and I think one is safe in saying, more human history also.

"Roosevelt was a many-sided man and every side was like an electric battery. Such versatility, such vitality, such thoroughness and such copiousness have rarely been united in one man. . . His Americanism reached in to the very marrow of his bones. The charge that he was an impulsive man has no foundation; it was a wrong interpretation of his power of quick decision. . . . His uncompromising character made him many enemies, but without it he would not have been the Roosevelt who stamped himself so deeply upon the hearts and the history of his countrymen."

This Memorial must reflect that character and translate it in unmistakable terms to the generations to follow.

Second, it must be essentially an educational institution. No other would adequately memorialize the broad, humanitarian intelligence that Roosevelt possessed. To those who wish to study nature in all its phases should be given every facility from every possible angle in order that they may appreciate and be led to emulate the extraordinary knowledge that Roosevelt attained.

Third, it should suggest a lofty standard of idealism through harmonious lines inspired by models chosen from the golden age of architecture. There should be evolved a design that will symbolize the spirit of Roosevelt, and by its impressiveness infuse those ideals for which Roosevelt strove and many of which he attained. The words of John Ruskin most aptly describe the goal of the builders of this Memorial:

"When we build, let us think that we build forever. Let it not be for present delight nor for present use alone. Let it be such work as our descendants will thank us for." 
Thus was started a great monument, dedicated to the perpetuation of the ideals of civic integrity, to the amelioration of those conditions which are oppressive, and to a fearless stride forward to hold the nation to a higher social and humanitarian level.

In 1924 the Legislature decided that the Memorial should be placed in New York City, adjacent to the American Museum of Natural History, and subsequently fixed the cost at a sum not exceeding $\$ 3,500,000$.

Governor Alfred E. Smith appointed a Board of Trustees as follows: The Governor, ex-officio; Henry Fairfield Osborn of Garrison, chairman; Peter D. Kiernan of Albany, vice-chairman; Chauncey J. Hamlin of Buffalo; Dr. Charles W. Flint of Syracuse; Sullivan W. Jones of Yonkers; Mrs. Douglas Robinson of New York City and Mrs. William H. Good of Brooklyn. In 1925, the Trustees decided to invite the leading architects of New York State to enter a competition and present plans for the Memorial. In this competition the design submitted by John Russell Pope of New York won the award.

The Program of Competition stated that "The nature lover should be stressed by monumental architecture, sculpture and mural paintings. The design should symbolize the scientific, educational, out-door and exploration aspects of Theodore Roosevelt's life rather than the political or literary." In Mr. Pope's plan these features are blended most harmoniously. A monumental structure, graceful in every line and inspired by the stately designs of the old Roman architecture, it conveys to the beholder an impression of spaciousness and enduring strength.

The facade is composed of three bays which are separated by great Ionic columns fifty-four feet high. The central bay, or great arch, extends to a height of about sixty feet above the floor of the terrace. In the bays at either side are framed windows surmounted by carved 
roundels embodying the Seal of The United States and the Seal of The State of New York respectively. In the frieze of the entablature over the columns are inscribed the three words, TRUTH, KNOWLEDGE, VISION.

The whole central portion of the facade is crowned by a parapet wall, against which are ranged four heroic figures over each of the four columns, Boone, Audubon, Clark, and Lewis, outstanding characters in the early history of the country. The central portion of the parapet bears the following inscription:

\title{
STATE OF NEW YORK MEMORIAL \\ To
}

\section{THEODORE ROOSEVELT}

\begin{abstract}
A GREAT LEADER OF THE YOUTH OF AMERICA, IN ENERGY AND FORTITUDE, IN THE FAITH OF OUR FATHERS, IN DEFENSE OF THE RIGHTS OF THE PEOPLE, IN THE LOVE AND CONSERVATION OF NATURE AND OF THE BEST IN LIFE AND IN MAN
\end{abstract}

These prominent features, together with its deep recesses, shadows, and reflections, and its mammoth bronze screened window, most successfully unite the exterior with the interior.

From the practical and educational standpoint the building is splendidly equipped with class rooms, exhibition rooms, a lecture hall, a hall for the display of the resources of New York State, and a room devoted to Rooseveltiana. At the right of the entrance vestibule are located the administration offices or 'Trustees' Room, while at the left is a group of superbly finished panelled butternut-wood interiors, forming a suite of rooms to be known as the Statesmen's Rooms. A cafeteria and lounge are located in the basement and from that floor direct access can be had to the platform of the Eighth Avenue Subway. 
The facade of the building is executed in a pinkish granite from Massachusetts. On the parapet wall surrounding the terrace are carved inscriptions indicative of the fullness of Roosevelt's life as follows: Ranchman, Scholar, Explorer, Scientist, Conservationist, Naturalist, Statesman, Author, Historian, Humanitarian, Soldier and Patriot. Upon the pedestals supporting the exterior columns and the pedestals flanking both ends of the terrace, which is 350 feet in length, Edward Field Sanford, $\mathrm{Jr}$., the sculptor, has carved in bas-relief the figures of animals native to America and Africa. A vehicular driveway adjoins this terrace, passing about the rear and leading to the first floor entrance.

In the center of the terrace, immediately in front of the great entrance arch, upon a polished granite pedestal, will be an equestrian statue of Roosevelt with two accompanying figures on foot, one an American Indian and the other a native African, representing his gun bearers and suggestive of Roosevelt's interest in the original peoples of these widely separated countries. This group will rise to a height of thirty feet above the sidewalk. It is the work of James E. Fraser, the well-known sculptor, who designed and executed the four statues that surmount the great columns on the main facade.

The niches at either side of the entrance are planned to hold sculptured figures of two typical specimens of American big game, the bison and the bear. It is intended that the bear shall typify courage, tenacity, and power; the bison, romance, fortitude, and endurance, dominant characteristics of Roosevelt. The arch itself is a coffered granite vault and in the background is a mammoth screen composed of bronze, glass, and marble, by means of which direct lighting of the interior hall is obtained.

Passing through this entrance, one steps into the Memorial Hall itself, a conception of grandeur and dig- 
nity in harmony with the spirit of Roosevelt's lofty ideals and fearless character. This hall, exclusive of recesses, is 67 feet wide by 120 feet in length. The floor is richly patterned in marble mosaic, the walls, to a height of nine feet, being of St. Florient cream marble surmounted by mellowed limestone extending to an elaborate Corinthian cornice and culminated by an octagonal coffered barrel vault, reaching to a height of 100 feet above the floor. At either end of this vaulted ceiling the walls are penetrated by large circular-headed windows which furnish the hall with ample daylight. In order to avoid the deteriorating effects of direct daylight on the murals, the architect has skilfully designed recesses in the walls at three sides of the room. These three recesses with a fourth containing the entrance arch have each two Roman Corinthian Columns forty-eight feet high supporting the entablature. The shafts are executed in Alacanti and Verona marbles, rising from a base of Botticino marble with hand-carved caps, each cap weighing seven and one-half tons. The wainscoting of the recesses is executed in Renfrew marble.

In the three great recesses have been placed mural paintings which form a most important part of the general decorative scheme and in themselves successfully portray the varied activities of Theodore Roosevelt. The artist, William A. Mackay, has given the north recess over to the subject "The Panama Canal," the south recess to "The Treaty of Portsmouth," and the west recess to "African Exploration." In these murals, covering a total area of five thousand two hundred and thirty feet, the artist has selected and skilfully presented the outstanding achievements rendered by Roosevelt both to our country and the world.

In the spaces within the Memorial quotations from Roosevelt's writings and sayings have been arranged under four headings as follows: 


\section{THEODORE ROOSEVELT MEMORIAL}

\section{NATURE}

THERE IS A DELIGHT IN THE HARDY LIFE OF THE OPEN THERE ARE NO WORDS THAT CAN TELL THE HIDDEN SPIRIT OF THE WILDERNESS, THAT CAN REVEAL ITS MYSTERY, ITS MELANCHOLY AND ITS CHARM THE NATION BEHAVES WELL IF IT TREATS THE NATURAL RESOURCES AS ASSETS WHICH IT MUST TURN OVER TO THE NEXT GENERATION INCREASED,

AND NOT IMPAIRED IN VALUE

CONSERVATION MEANS DEVELOPMENT AS MUCH AS IT DOES PROTECTION

\section{MANHOOD}

\section{A MAN'S USEFULNESS DEPENDS UPON HIS}

LIVING UP TO HIS IDEALS IN SO FAR AS HE CAN IT IS HARD TO FAIL, BUT IT IS WORSE NEVER TO HAVE TRIED TO SUCCEED

ALL DARING AND COURAGE, ALL IRON ENDURANCE OF MISFORTUNE - - MAKE FOR A FINER, NOBLER TYPE OF MANHOOD

ONLY THOSE ARE FIT TO LIVE WHO DO NOT FEAR TO DIE; AND NONE ARE FIT TO DIE WHO HAVE SHRUNK FROM THE JOY OF LIFE AND THE DUTY OF LIFE

\section{YOUTH}

I WANT TO SEE YOU GAME, BOYS, I WANT TO SEE YOU BRAVE AND MANLY, AND I ALSO WANT TO SEE YOU GENTLE AND TENDER BE PRACTICAL AS WELL AS GENEROUS IN YOUR IDEALS, KEEP YOUR EYES ON THE STARS AND KEEP YOUR FEET ON THE GROUND

COURAGE, HARD WORK, SELF-MASTERY, AND INTELLIGENT EFFORT ARE ALL ESSENTIAL TO A SUCCESSFUL LIFE

CHARACTER, IN THE LONG RUN, IS THE DECISIVE FACTOR IN THE LIFE OF AN INDIVIDUAL AND OF NATIONS ALIKE

\section{THE STATE}

OURS IS A GOVERNMENT OF LIBERTY BY, THROUGH, AND UNDER THE LAW A GREAT DEMOCRACY MUST BE PROGRESSIVE OR IT WILL SOON CEASE TO BE GREAT OR A DEMOCRACY AGGRESSIVE FIGHTING FOR THE RIGHT IS THE NOBLEST SPORT THE WORLD AFFORDS

IN POPULAR GOVERNMENT RESULTS WORTH WHILE CAN ONLY BE ACHIEVED BY MEN WHO COMBINE WORTHY IDEALS WITH PRACTICAL GOOD SENSE IF I MUST CHOOSE BETWEEN RIGHTEOUSNESS AND PEACE I CHOOSE RIGHTEOUSNESS 
The first floor has been designated the "New York Hall." In the hall proper, four large groups will be installed in the spaces provided, depicting scenes pertinent to Roosevelt's interest in natural history and exploration, i. e., "Western Ranch Life," "The Bird Sanctuary at Oyster Bay," "On the River of Doubt," and "African Exploration." At this writing positive decision regarding the subjects has not been made by the Trustees, but thus far these above-mentioned subjects have been more appealing than any others submitted. In the corridors surrounding the hall, cases containing specimens of birds, mammals, fishes, reptiles, and amphibians typical of the state will be installed. On the wall spaces are four tablets entitled "Theodore Roosevelt," "Building the Memorial," "Geology and Paleontology of America," and "Natural History of New York." Other spaces will contain matter devoted to New York State's outstanding position in the world of natural science.

On the axis of the great hall, and from within the receptive recesses, monumental doorways with massive bronze doors lead directly into a wide, encircling corridor. This corridor provides a spacious connection to the present and future wings of the Museum, to the stairways and elevators, to the class rooms, educational and exhibition rooms. The doorway opposite the main entrance connects not only with the corridor, but leads to the future Akeley African Hall. Since Mr. Akeley and Colonel Roosevelt were co-workers and companions on several hunting expeditions and on the latter's trip to Africa, it seems most fitting to perpetuate this close relationship in such a lasting association of memorials.

The third and fourth floors are given over to science and class rooms. On the fifth floor is an unusually fine auditorium, seating six hundred people, completely equipped for sound and moving pictures including stere- 


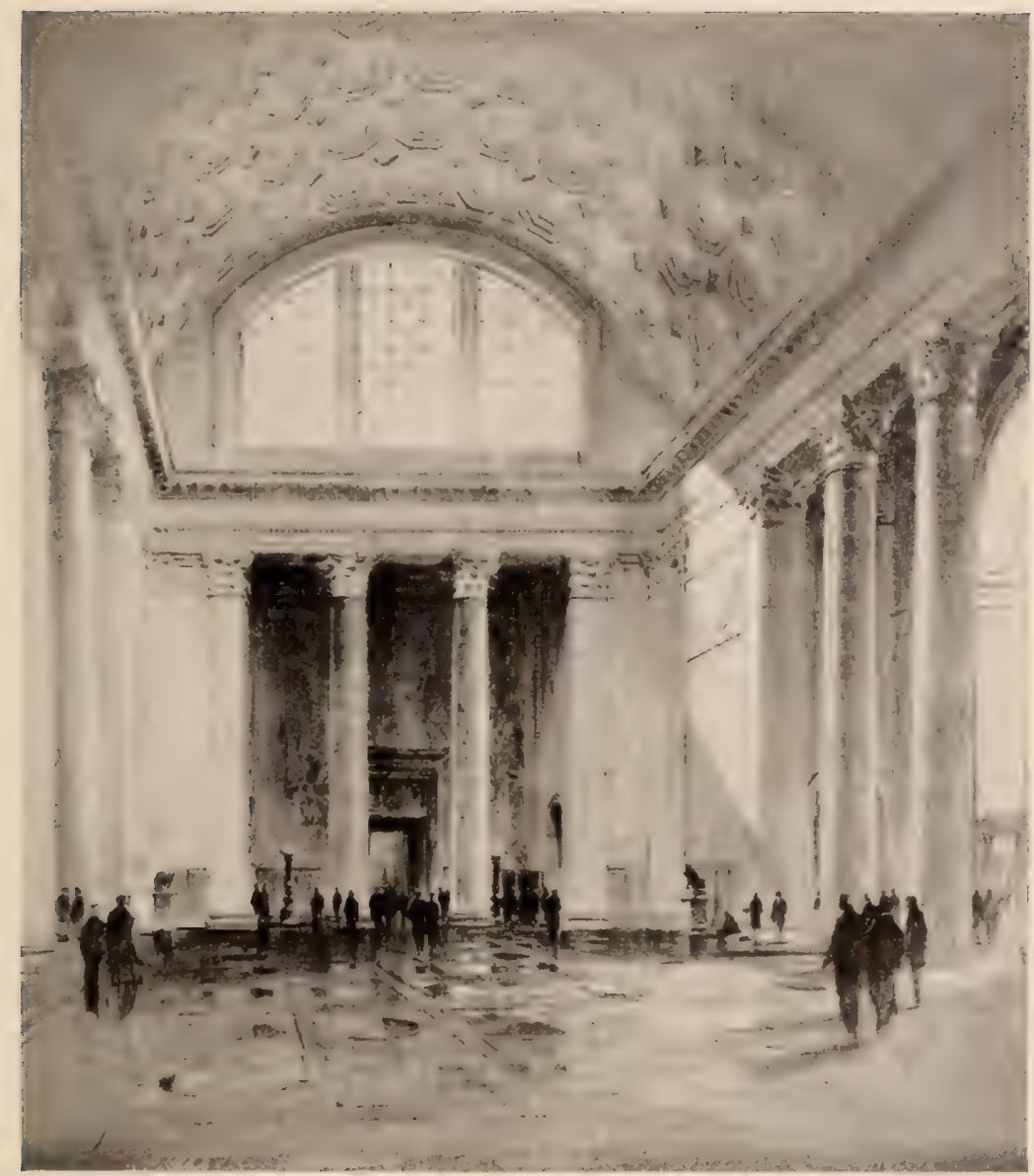

INTERIOR OF MEMIORIAL HALL

This great memorial hall is 67 feet wide and 120 feet long, and reaches 100 feet above the floor. With walls of marble and mellowed limestone, it forms a material conception of grandeur and dignity 

opticons, which will be available for educational societies and gatherings of all kinds.

The late Chairman Osborn, assisted by Secretary Pindar, labored, often under great difficulties, to secure the appropriations for this Memorial which they felt would be a powerful influence for the dissemination of patriotic ideas and to instruct future citizens, both American and foreign born, in the responsibilities of freedom; and to make this a living tribute to the memory of a man whose chief thought and hope and deed was directed toward the betterment of his fellow man through a liberal and broad-minded education.

On July 25, 1929, the deed of land for the Memorial was received from the city of New York. On September 24 , bids for the foundations and sanitary work were opened and the contracts awarded. On October 16, 1929, Secretary Pindar turned over the first shovelful of earth to start the construction and the great Memorial was under way.

In April, 1930, with the approval of the Governor, there was included in the State bond budget an allocation of $\$ 2,100,000$ for the continuance of the building program, and on November 25, 1930, the contract for the superstructure was awarded.

After Chairman Osborn accomplished the objective of the Memorial in 1924, he turned his attention to the matter of a proper approach from Central Park to the building. The plan of the Approach as designed by the architect, John Russell Pope, provides for a concourse 160 feet wide and almost 500 feet long, consisting of a broad central space for lawn, flanked on either side by wide drives bordered with ginko trees or elms shading foot paths still farther removed from the central green, the whole running from the west drive of Central Park to the Memorial Building. 


\section{THEODORE ROOSEVELT MEMORIAL}

The vista opening from such a drive showing the stately facade of the Memorial and the remarkably fine equestrian statue of Roosevelt by the sculptor, James E. Fraser, will be striking. No visitor in Washington approaching the Lincoln Memorial from the Mall can question the mutual enhancement of both landscape and architecture in the combination of a deep, formal approach with the monument.

In the case of the Roosevelt Memorial, in addition to its architectural value and utilitarian features as a direct approach, such a tree-bordered concourse with its wide open vista will no doubt attract numerous visitors passing through the park who might otherwise, with the present screen of foliage, be entirely oblivious of the proximity of this national monument and the beauty of its architecture The importance of this Approach has never been lost sight of since the Memorial was decided upon.

To envisage the Roman architectural quality of simple, restrained detail in the building proper, executed in such massive proportions as has been afforded, the broad paved terrace, and at its focal point, the equestrian group rising to a height of some thirty-four feet, the construction of this approach will not only enhance the present beauties of the building, but will provide the setting required by the importance of such a noble and noteworthy monument.

The details of the three large mural paintings which form such an important and essential feature in the composition of the Memorial, have been outlined by the artist, William Andrew Mackay, as follows: 


\title{
WEST PANEL
}

\author{
Roosevelt's African Expedition
}

Reproductions and Descriptions 


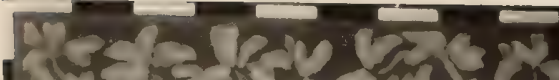

$11+2=15 \mathrm{~m}: 22 \mathrm{w}$

visil on

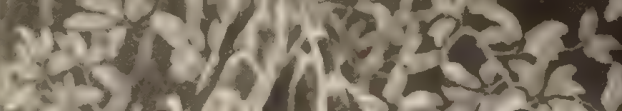

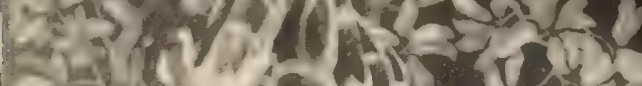

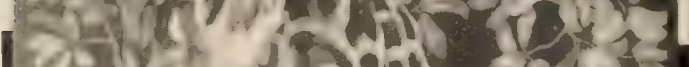

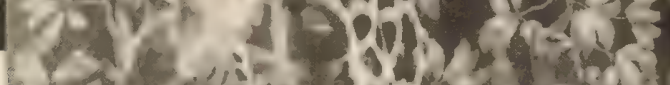

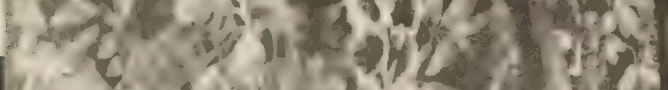
(10.8.

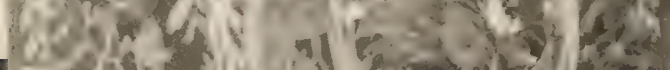

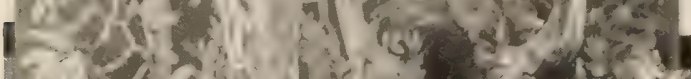
ditans: Hexty

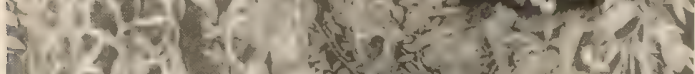

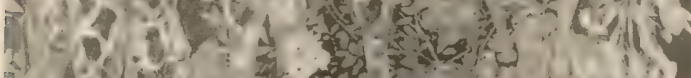

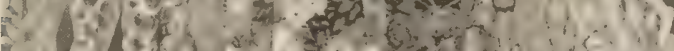

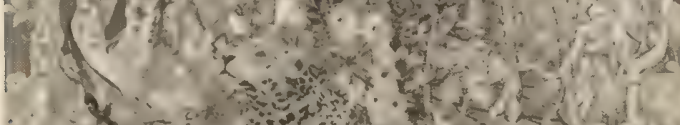
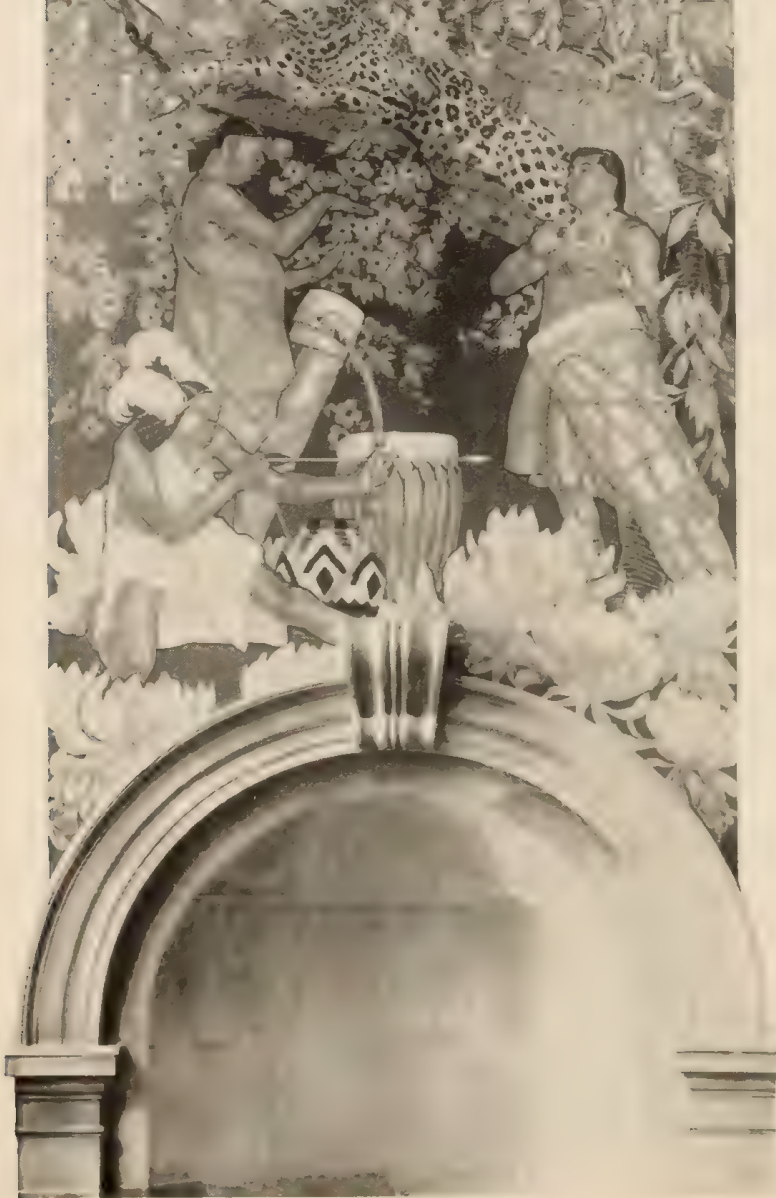

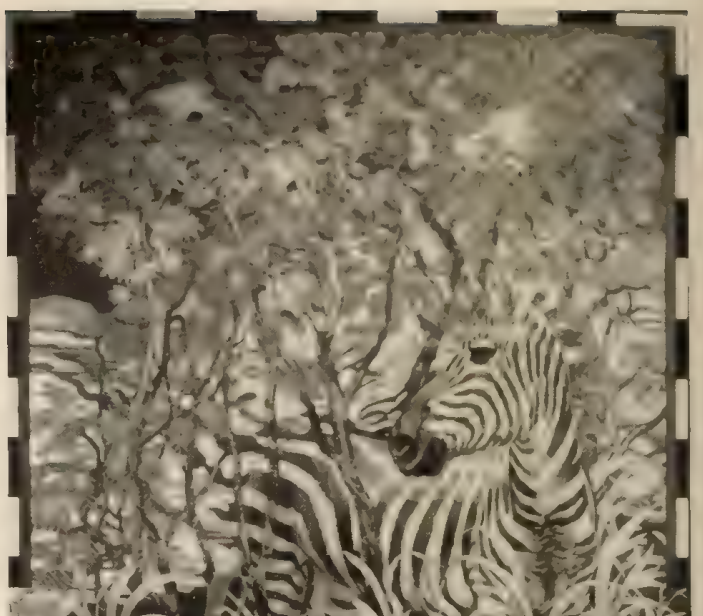
Ex âे

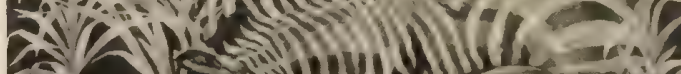

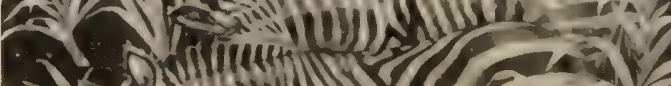
1)

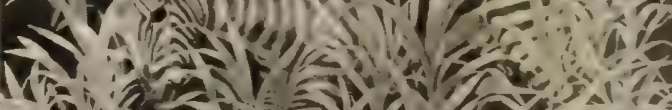

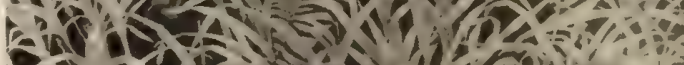

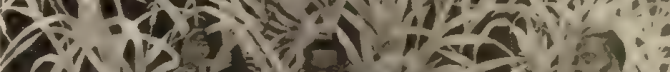

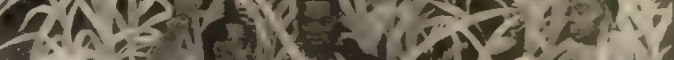

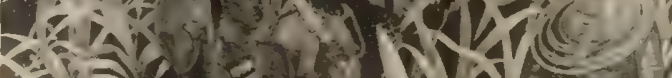

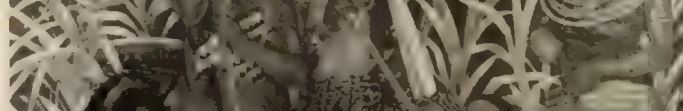

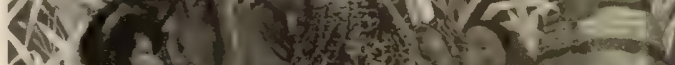
Mal

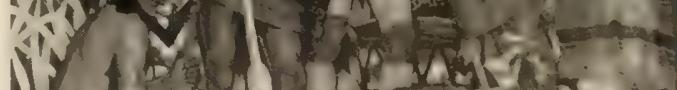
Now Nomo

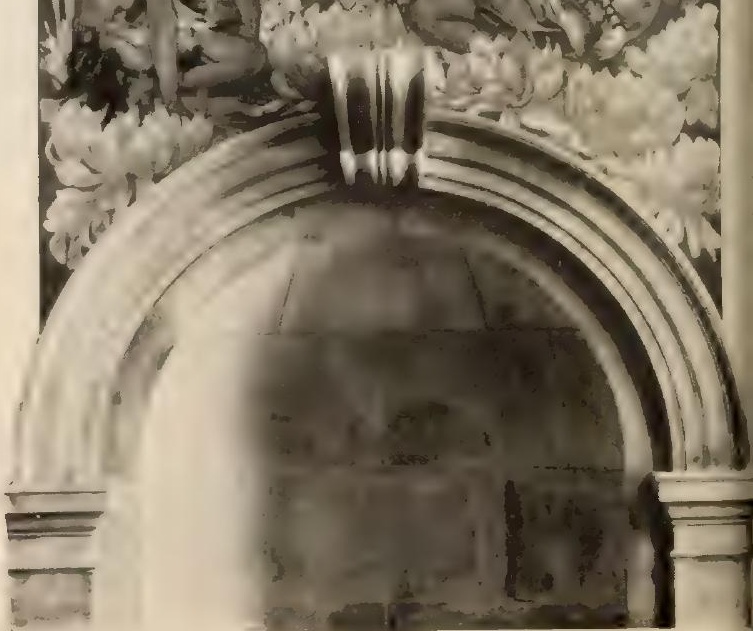

(1) W. A. Mackay Co. 


\section{ROOSEVELT'S AFRICAN EXPEDITION}

\section{Left Return Panel}

At the base are individuals of a typical African tribe with tom-toms and native weapons. Above them in conventionalized leafage are a

leopard intently watching a squirrel on a broken bough, a giraffe with its young, and an ostrich.

\section{Right Return Panel}

At the bottom are again depicted characteristically garbed tribal members, surmounted by an early morning landscape in which are mingled the decorative lines of the thinly-leafed trees, grasses, and the stripes of a species of African zebra. 


\section{ROOSEVELT'S AFRICAN EXPEDITION}

\section{Central Panel}

At the bottom left.-Grouped about the shield are natives on safari carrying the weapons and baggage of an expedition. This procession is complementary to the departure of $\mathrm{Ham}$ on a much earlier journey into the wild interior of Africa.

Above stands Theodore Roosevelt with his gun-bearers over a Nubian lion and lioness and other typical African animals and birds. Examining this group are Science, in academic robes, a Girl and a Boy Scout. The last named figure is symbolic of Theodore Roosevelt's participation in the organization of the Boy Scouts of America.

Over the doorway.-Against an outline map of the northern section of Africa is portrayed the dispersal of the sons of Noah-Shem, Ham and Japheth-after the voyage of the Ark. Cursed by his father for disrespect, $\mathrm{Ham}$ with his son Canaan and all their descendants, were destined to perpetual slavery. Ham and his wife appear at the center, the brothers Shem and Japheth ready to go their several ways, while the members of Ham's family appear at the left, facing, as it were, their entry into Africa. Various African animals appear here, and at the left is Mount Kenya, with a bamboo forest in the foreground.

In the middle right among gnarled trees is an African elephant attacked by native hunters with their primitive spears.

At the bottom right the motive of the safari is repeated with Kermit Roosevelt as leader, behind the native holding the shield of the Smithsonian Institution in Washington, under the auspices of which Theodore Roosevelt's African explorations were undertaken in 1910. 



\section{SOUTH PANEL}

\section{The Treaty of Portsmouth, I904}

Reproductions and Descriptions 

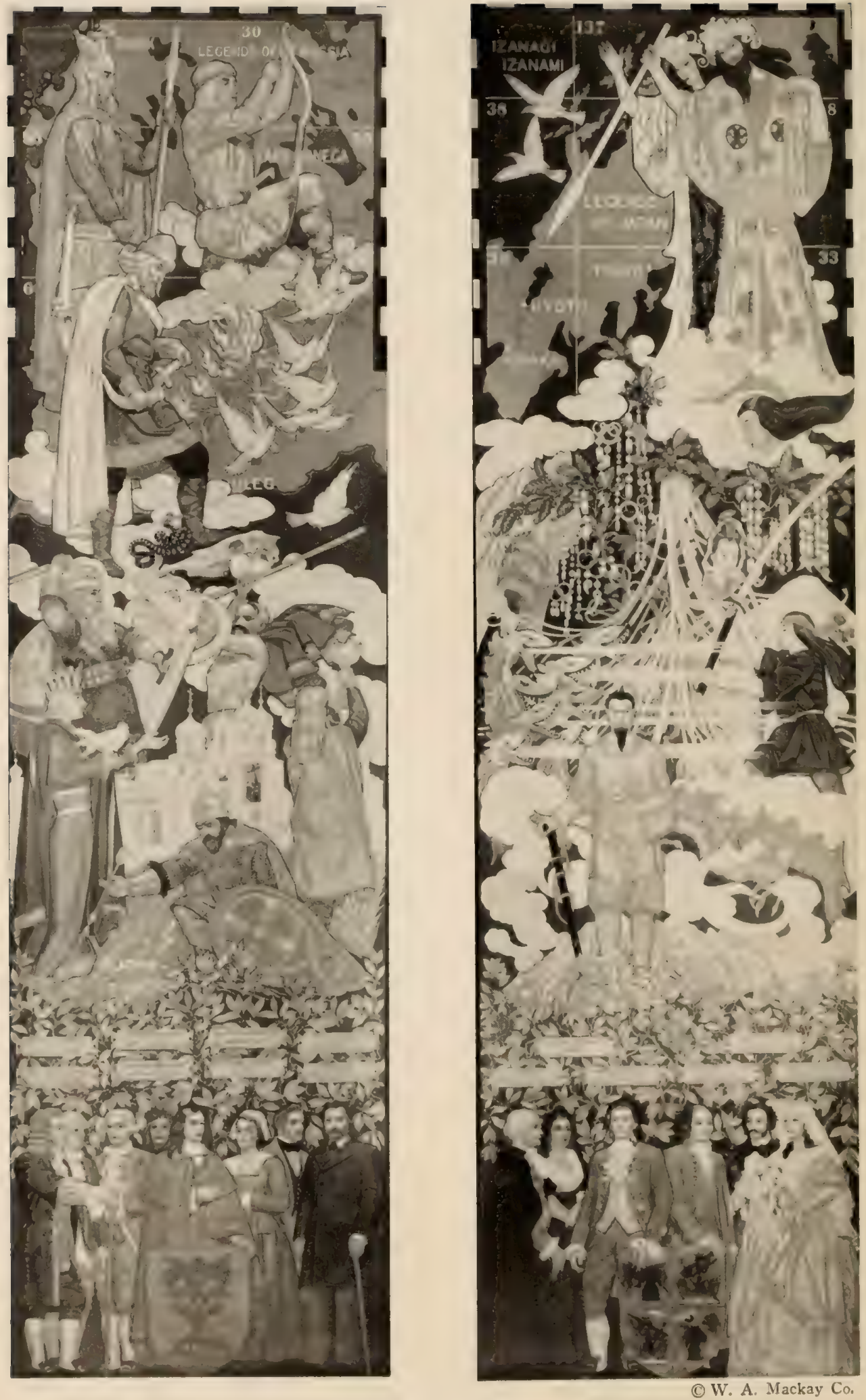


\section{THE TREATY OF PORTSMOUTH, 1904}

\section{Left Return Panel}

Is devoted to early Russian legendary history. At the top is a primitive North Russian kneeling to string his bow. Near him, holding a spear and shield is the Norseman, Rurik, first historic ruler of a federation of Slavic tribes in a unified State. The map background indicates the region of Novgorod, where Rurik first established his power.

Next below is Oleg, companion and brother-in-law of Rurik, who became Regent in 879 A. D. during the minority of Igor, son and heir of Rurik. Oleg was killed by the bite of a snake hidden in the skull of his horse in 913 A. D., thus fulfilling a prophecy that his horse would be the cause of his death.

Igor, son of Rurik, is shown fighting with a Greek warrior, typifying his wars with the Greeks in 941-944 A. D. Igor's queen, Olga, held the Regency while her son, Sviataslaw, was a child. She is shown releasing pigeons, the only tribute she had demanded from her enemies, who carried fire back to the thached roofs of their former owners. Thus she avenged the deaths of her husband and son.

The figure on the right is the chief of the enemies who slew the son, Sviataslaw, and the drinking-cup he holds is the skull of his victim, on which is the inscription "He who grasped at the possession of others, lost all that was his own." In the background is a Russian church; Olga first introduced Christianity into Russia. Her grandson, Vladimir, beseiged and finally captured a Greek city after cutting off its water supply, he having received a message tied to an arrow shot into his camp which disclosed the water sources of the city. Vladimir married the princess of the fallen city, and this union resulted in the introduction of Greek Orthodoxy into Russia as its established religion.

At the bottom of this panel are pictured the ancestors of the Roosevelt family, grouped about their armorial shield.

\section{Right Return Panel}

Against a background of the map of Japan, and standing upon "The Floating Bridge of Heaven," are the gods of Japanese tradition, Izanagi and Izanami. They thrust a spear into the ocean and the falling drops created an island, where they lived and became the parents of the Sun Goddess, Ama-terasu.

Ama-terasu appears below, where she has retreated into "The Rock Cave of Heaven" to avoid her unruly brother Susa-No-O. When she refused to see him before his banishment to the Land of Yomi (Hades), the Gods and Goddesses were much disturbed at the prospect of darkness. They planted a Sakaki tree before the cave and upon it hung a mirror, a rosary of jewels, and offerings of cloth. They finally induced the Sun Goddess to look forth from her cave to see a goddess more beautiful than she. Seeing her reflection in the mirror, she came out of the cavern. Tasuki, the Moon God and consort of the Sun Goddess, is shown with her.

Below is Susa-No-O in the act of slaying the seven-headed serpent after it had drunk a quantity of rice wine. The sacred mountain, Fujiyama, appears in the background, and in the foreground is the first historic Emperor of Japan, Jimmu, a descendant of the Sun Goddess.

At the bottom of this panel, are pictured the maternal ancestors of Theodore Roosevelt, the Scotch family of Bulloch. 


\section{THE TREATY OF PORTSMOUTH, 1904}

\section{Central Panel}

At the bottom left.-Delegates from Russia and Japan are gathered at the council table to negotiate to bring an end to the Russo-Japanese War.

A representative from each country lays upon the table a palm branch, emblem of Peace. Theodore Roosevelt stands at the head of the table, Columbia behind him. The delegates are: Baron Komura, Japan; C. Nabokoff, Count S. de Witte, J. Korostovetz, Russia; M. Takahira, Japan.

At the left, next above.-Russians slain in battle lie in a wheatfield where a Russian priest, attended by a deacon, offers prayers; and a Russian Red Cross nurse, holding a taper, stands with the mourners. Near the doorway are the figures of Death, Famine and Pestilence; a condor perches on a war-shattered tree. In the background are the destructive fires of war.

At the left, top.-Early conflicts of Russians and Mongol Tartars are indicated, the contestants with characteristic weapons and war gear.

Above the doorvay, is a map of northern Asia, showing parts of Mongolia and China, the course of the Great Wall, Korea and Japan. Against the background of this map appear the figures of Genghis Khan, flanked by two of his four sons, and supported by warriors of the period. The Kahn's fame and historic importance is due to his extensive conquest of the peoples of surrounding countries. At his feet is a heap of ornaments and jewels, remindful of his pillaging proclivities.

At the right, top, is repeated the theme of the early conflicts of the Mongol Tartars with, here, the Japanese in the armour of the period and Japanese archers with long bows.

On the right, balancing the group on the left of the doorway is, first, the Japanese Goddess of Mercy, "Kwannon," her head encircled by a halo. There is a Shinto priest and a group of mourners, the counterpart of the Russian group, with the differences of racial type and costume. The identity of pattern and theme suggests the equal loss and ruin suffered by both parties in war.

At the bottom, right, is the Japanese Emperor in ceremonial vestments, with his armorial device in gold on a blue banner. The ensign of Japan shows a red sun and its rays upon a white ground; the ensign of Imperial Russia is a blue diagonal cross on a white ground. The Imperial Eagle, double-headed, was the standard of the Russian Tzar, who is featured on the extreme right offering his sword, as does the Japanese Emperor. Japanese and Russian soldiers in conflict are separated by the intervention of Justice and Mercy. 



\title{
NORTH PANEL
}

\author{
The Panama Canal
}

Reproductions and Descriptions 

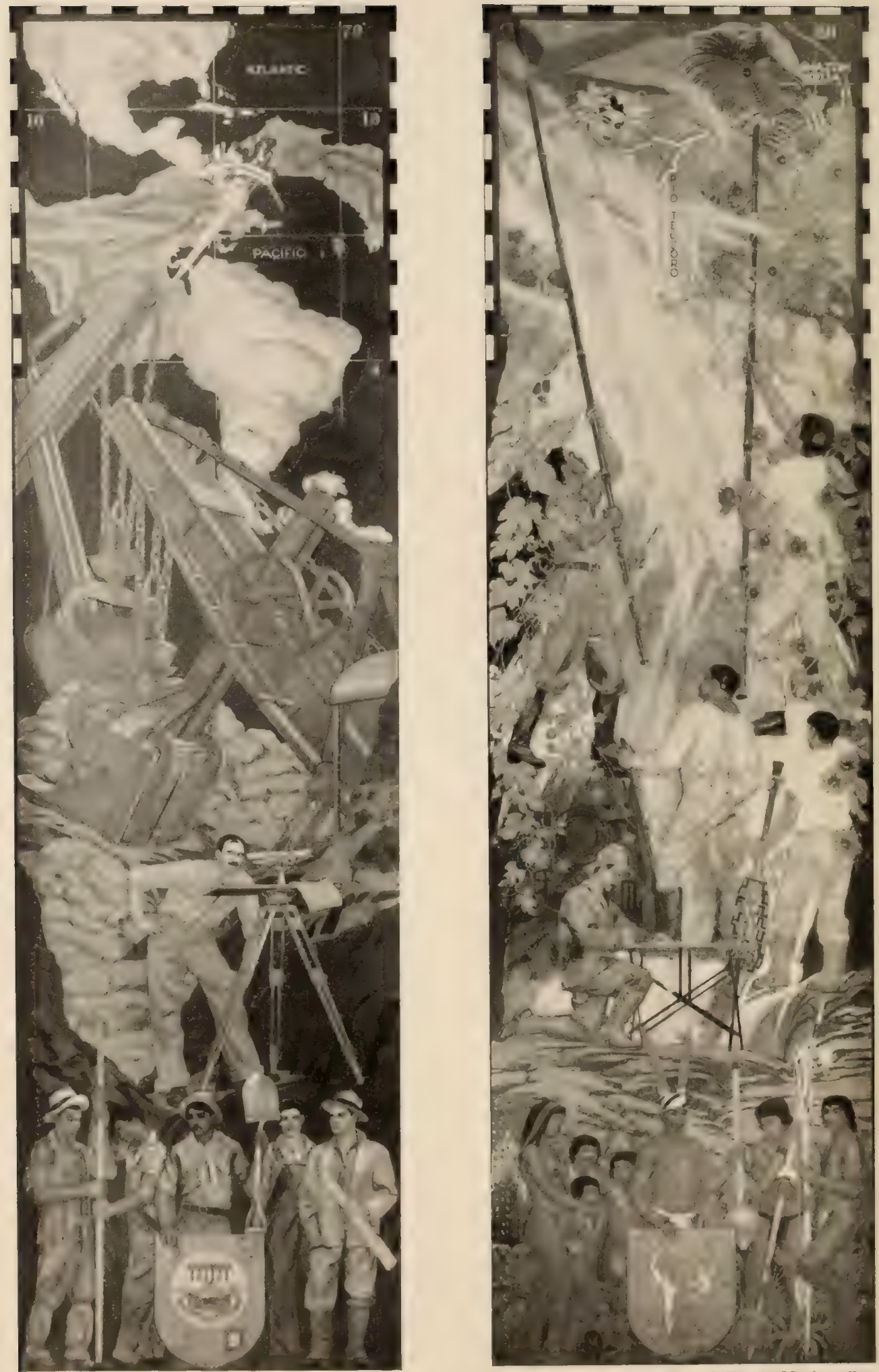

(c) W. A. Mackay Co. 


\section{THE PANAMA CANAL}

\section{Left Return Panel}

This panel portrays a dramatic part of the construction in the excavation for the Panama Canal, and shows the meeting of two great steam shovels facing each other in the work of dredging the last earth and rock of the excavation. Below the machinery, at an engineering plane-table is the figure of an American construction engineer.

At the bottom. - The central figure holding the shield is a typical LatinAmerican Canal laborer. The shield of the Canal Zone represents the coat of arms of the Zone, surrounded by those of France, Spain, Scotland and Portugal. At the right are typical figures engaged in the building of the Panama Canal, and at the left are two natives using a loading iron, making preparations for blasting.

\section{Right Return Panel}

The ancient goddess of the river pours from a vessel "The Unknown River" in South America, discovered and explored by Theodore Roosevelt and later named "Rio Teodoro." The discoverer views the river at its source, his native attendants with their propelling poles pushing aside the branches, disclosing the stream. Kermit Roosevelt is shown in the foreground recording the discovery.

At the bottom, are members of the Parecis tribe of Indians, with a warrior holding a decorative shield showing the map of South America and the arms of Portugal and of Brazil, and in his left hand a primitive musical instrument. 


\section{THE PANAMA CANAL}

\section{Central Panel}

At the bottom left the figures grouped about the shield of Panama represent early founders in the development of this region. At the extreme left is a Mayan warrior, at the extreme right a Mayan priest. The headdress of these figures is a crown-like structure adorned with feathers. Next to the Mayans, on left and right are Aztecs carrying weapons: left a spear with flaming feather head and a huge chipped spear-point; right a sling and bag of stones with a spiral design, a typical Aztec emblem.

Standing on the outline map of the canal district are Father Time, a woman holding the tug-boat Gatun, the first craft to pass through the Canal from the Atlantic Ocean, and Neptune.

Immediately above these figures are five women dressed in typical Spanish costumes displaying various products of the South American continent for which the Canal provides facilities for export.

Then are represented two pirates, a Mayan holding on a staff the Quetzal bird, and at the top left pirate ships in combat with early settlers, and three shields displaying a Mayan emblem on a blue field, a Toltec emblem on a red field, and the Aztec emblem of an eagle holding a snake in its beak which remains the emblem of the Republic of Mexico at the present time.

Above the doorway is a map of the Canal Zone showing the boundaries and water courses, with the Canal itself indicated by a red line.

At the top right three shields display respectively the arms of Balboa, discoverer of the Pacific Ocean, his Spanish sovereign, and (a later insignia) the shield of republican France under which government Count de Lesseps first initiated the scheme of a canal across the Isthmus. To the left, below these shields, stands Balboa with the Standard of Spain. Beside him is a pirate holding a model of his ship and a bag of gold, and carrying a native monkey on his shoulder. Next to the pirate, at the right, is a Mayan noble holding a ceremonial bar, insignia of his high rank. Beneath these is Sir Henry Morgan, richly dressed in red, a raider of the Spanish Main and eventually Governor of Jamaica. Here, also, is a wrecked and rusted French excavating machine covered with leaves, remnants of which may still be seen beside the banks of the Canal. Nearby is a French army officer, and Count de Lesseps in white with the symbolic figure of France behind him.

In the middle right President Theodore Roosevelt is discussing plans with Chief Engineer John F. Stevens. At the left an officer holds the flag of the Engineer Corps, United States Army. At the right is an officer of the Medical Corps, United States Army, with a test-tube, a symbol of the research into the causes of pestilence. Below him a Negro sprays the ground against the mosquito pest, the carrier of yellow fever and the cause of the failure of the French in their heroic effort to build the Canal. Nearby, laborers hold a steam drill and crow-bar. Below them is a model of the Gatun Locks.

At the bottom right.-Color sergeants display the flag of the militia of the District of Columbia and the President's flag, with attendant elements of the Great Seal of the United States. The figures of Freedom at the left and Liberty on the right support a shield bearing the inscription:

"President Roosevelt took possession of the French canal property May 4, 1904. The land divided, the world united. Completed 1914." 



\section{ADDRESSES AND PROCEEDINGS AT DEDICATION}

OF

NEW YORK STATE THEODORE ROOSEVELT MEMORIAL

NEW YORK CITY, JANUARY 19, 1936

Secretary Pindar called the assemblage to order and requested that all rise and join in singing "America" to be led by the "Boy Scouts of America."

\section{AMERICA}

Samuel Francis Smith

1832

My Country, 'tis of thee,

Sweet land of liberty,

Of thee I sing;

Land where my fathers died,

Land of the pilgrims' pride,

From every mountain-side

Let freedom ring.

My native country, thee,

Land of the noble free,-

Thy name I love;

I love thy rocks and rills,

Thy woods and templed hills;

My heart with rapture thrills

Like that above.

Our Fathers' God, to Thee,

Author of liberty,

To thee I sing;

Long may our land be bright

With freedom's holy light;

Protect us by Thy might,

Great God our King.

At the conclusion of the hymn the Secretary turned the Program over to Vice-Chairman Kiernan. 


\section{ADDRESS BY MR. PETER D. KIERNAN}

Mr. President, Governor Lehman, Mayor LaGuardia, Members of the family of Theodore Roosevelt, and Distinguished Guests :

On behalf of my Associate-Trustees and myself, I wish to acknowledge our sincere appreciation of the signal honor the President has conferred by his presence here today.

We are gathered here to dedicate this magnificent Memorial erected by the Imperial State of New York to the memory of a man whom the world hailed as a great American-Theodore Roosevelt.

Seventeen years ago, January Sixth, Nineteen Hundred Nineteen, Theodore Roosevelt reached the end of the long trail. Every nation of the world paused to pay tribute to his eminent qualities of head and heart.

Two distinguished metropolitan newspapers, The Times and The World, editorially suggested that the State of New York should commemorate in enduring form the achievements of her great son.

One man, the late Professor Henry Fairfield Osborn, was inspired to undertake that task. From that time to the day of his death he labored with a tireless zeal and with a tenacity of purpose which brooked no obstacle. It is due solely to the invincible will of Professor Osborn that this great Memorial was conceived and executed.

It is my profound regret that as Vice-Chairman of the Roosevelt Memorial Commission, it becomes my duty to preside today. That honor belonged to Henry Fairfield Osborn, and if his spirit is looking down upon this assemblage, I hope it will give his benediction to our proceedings. 
If Professor Osborn were here today he would convey his high appreciation of the warm and enthusiastic cooperation which Governor Franklin D. Roosevelt gave to make this Memorial a reality; he would describe the ceremonies incident to the Governor's laying of the corner stone on October 27, 1931; he would relate Governor Roosevelt's appeal to the Legislative leaders for an appropriation which would permit the erection of a building that would do full justice to the distinguished service Theodore Roosevelt had given to the City, State and Nation, and particularly that it should be an inspiration to the youth of the Nation.

Mr. President,--if we have been successful in translating your ideas and ideals in this edifice - if in this splendid hall with its lofty columns we have succeeded in capturing that heroic note which dominated the man you affectionately call "T. R." - if in the selection of some of his most striking phrases, which are inscribed upon these walls, we have achieved that note of inspiration to the Youth of the country, which you as Governor impressed upon us, we are content.

Ladies and Gentlemen, I have the great honor to present:

The President of the United States 


\section{ADDRESS BY \\ PRESIDENT FRANKLIN D. ROOSEVELT}

Mr. Chairman, Governor Lehman, Mayor LaGuardia, Trustees of the New York State Roosevelt Memorial, Trustees of the American Museum of Natural History, Ladies and Gentlemen:

This Memorial, the corner stone of which I laid, and in the dedication of which I am privileged to participate this afternoon, is typical of Theodore Roosevelt. It reflects the universality of his mind and of his interests. Its decorations-in place or in planning-tell part of the story of his life, his work, and his play; they depict the construction of the Panama Canal in which he was the dominating spirit; the Treaty of Portsmouth, which ended the Russo-Japanese War; the quest for scientific knowledge which carried him into the African Jungle; symbolic figures of Fauna and Flora to tell generations to come of his interest in nature and in conservationall these bear witness to his intense vitality and to his varied contributions to our national culture. The Roosevelt Memorial Commission has been faithful in executing its high trust.

The quotations on these walls, too, bring us their message out of the rich storehouse of his written words.

"Conservation means development as much as it does protection"-a text which ought to be emblazoned in every treatise on the care and perpetuation of our national resources.

Or this: "The nation behaves well if it treats the natural resources as assets which it must turn over to the next generation increased, and not impaired, in value."

From his writings in the realm of state craft we find this: "A great democracy must be progressive or it will 
soon cease to be great or a democracy." It is his warning to us of this day and generation that eternal progress is still the price of liberty.

It is fitting that this memorial perpetuating the life and work of one who stirred such great interest in the field of natural history should itself be an adjunct of the American Museum of Natural History. And may I say that I am very proud of the fact that for forty years I have been a member of this museum. My friend, and our friend, the late Professor Henry Fairfield Osborn, so long the head of this noble institution for the increase and diffusion of scientific knowledge, and for many years a devoted colleague of him in whose honor we are gathered today, advocated this memorial soon after Theodore Roosevelt's death.

Each and every one of us feels sadness today that Professor Osborn could not have lived to take his part in this, the culmination of this great desire. We know that his spirit is with us.

This memorial of such noble architectural proportions, is withal intimate and vital. Above all things it is useful. There was an intimate equality about Theodore Roosevelt which all of us who knew him recall at this hour. We think of him, not as an abstract being, dwelling apart on the heights, but rather as a friendly soul pervading this very hall which we are dedicating to his memory.

Theodore Roosevelt possessed talents and abilities which we know today were unusual, even among the leaders of men. Whatever he did, he did with all his might.

With this spirit of vital activity, be it also remembered that he received the Nobel Peace Award. In him was combined a passion for righteousness and that strong sense of justice which found expression in the "Square Deal." Race, creed, color, were not determining factors with him. He took a man for what he was. 


\section{THEODORE ROOSEVELT MEMORIAL}

"A man who is good enough to shed his blood for his country," said he at Springfield, Illinois, on a 4th of July, "is good enough to be given a square deal afterwards. More than that no man is entitled to, and less than that, no man shall have."

In his first Message to Congress he had written: "The most vital problem with which this country, and, for that matter, the whole civilized world, has to deal, is the problem which has for one side the betterment of social conditions, moral and physical, in large cities, and for the other side the effort to deal with that angle of far-reaching questions which we group together when we speak of 'labor.'"

Yes, this creed for social justice may be found in many quotations from later messages. He said:

"In the vast and complicated mechanism of our modern civilized life, the dominant note of industrialism, and the relations of capital and labor, and especially of organized capital and organized labor, to each other and to the public at large, come second in importance only to the intimate questions of family life.

"The corporation has come to stay, just as the trade union has come to stay. Each can do and has done great good. Each should be favored as long as it does good, but each should be sharply checked where it acts against law and justice."

You and I still remember how those whom he denounced with righteous wrath winced under the stigma of such flashing epithets as "malefactors of great wealth," "the wealthy criminal class," and "the lunatic fringe." He had a gift for pungent phrases and boiled down his whole political philosophy into such a homely and popular maxim as "speak softly but carry a big stick." No wonder that John Morley said in 1904: "The two things 
in America which seem to me most extraordinary are Niagara Falls and President Roosevelt."

With clearness of vision, energy, unfaltering faith, he labored through his entire career to transform politics from a corrupt traffic to a public service. With a very passion for justice and equality before the law he sought with voice and pen, with every resource at his command, to obtain for men everywhere their constitutional guarantee of life, liberty and the pursuit of happiness.

I have purposely emphasized the many-sidedness of his character. That extraordinary range of interests makes difficult the task of anyone who would adequately summarize his career and achievements. Varied as were his political activities, the scope of his literary interests was no less extended. His volumes on American history, on current problems, and on his own experiences as hunter and explorer, captured, as we know, and retained the interest of the American people.

We know how he loved the great outdoors. He loved the life of the boundless plains which he had known as a rancher in the west. He found strength in the wilderness. He knew the birds and the animals and the trees and the plants and the flowers.

And so he worked and so he wrought and so he wrote. His familiarity with all literature, with history and biography, was reflected alike in his private writings and in his public utterances. Who but he could have given Bunyan's "Man with the Muckrake" an emphasis which he gave it thirty years ago so that the term "Muckraker" passed into the language and is current with us even to this day?

He enriched, he enlarged and extended our cultural horizon. Out of the rich experiences he had known, his mind received a cast which later was reflected when he 
infused action and life and color into what before his time had been a somewhat dull and drab state-craft.

Everything about him was big and vital, and above all national. He was able to see great problems in their true perspective, because he looked at the Nation as a whole. There was nothing narrow or local or sectional about that man. It is not for me here today to speak of the final place which history will accord Theodore Roosevelt; but we know and the Nation knows and, yes, the world knows, that Theodore Roosevelt was a great patriot and a great soul.

When he died, the Secretary of his class at Harvard, in sending to his classmates a notice of his passing, added, at the end, this quotation from "Pilgrim's Progress":

"After this it was noised abroad that Mr. Valiant-fortruth was taken with a summons by the same post as the other, and had this for a token that the summons was true "That his pitcher was broken at the fountain.' When he understood it he called for his friends and told them of it. 'Then he said, 'I am going to my Father's, and though with great difficulty I have got hither, yet no, I do not repent me of all the trouble I have been at to arrive where I am. My sword I give to him that shall succeed me in the pilgrimage, and my courage and skill to him that can get it. My marks and scars I carry with me, to be a witness for me that I have fought His battles who now will be my rewarder." " 


\section{REMARKS BY MR. PETER D. KIERNAN \\ WITH TENDER OF MEMORIAL TO GOVERNOR LEHMAN}

The tribute which the President has just paid to the memory of Theodore Roosevelt will long be remembered by all those present, and by millions of radio listeners.

This event is one of historic interest. The President is the leading participant in the dedication of a Memorial erected to the memory of one of his most distinguished predecessors, one who was also united to him by ties of name and kinship.

Years, perhaps centuries, will pass before a similar event will be repeated in this nation.

It is very interesting to recall that three Governors of this State have played their part in the development of this project. It was initiated during the administration of Governor Alfred E. Smith, who gave it his loyal and unqualified support. Governor Roosevelt's part I have already described. It was completed under the administration of Governor Lehman.

In some respects, Governor Lehman had the most difficult part. Naturally, in a project of this magnitude unforeseen difficulties occur, which only time develops. In all our difficulties Governor Lehman was more than helpful; through his cordial support we were able to surmount difficulties as they arose.

Governor Lehman, - the Trustees appointed by you and your predecessors, Governor Roosevelt and Governor Smith, now report to you that the work which was assigned to them has been completed.

A famous architect, John Russell Pope, designed this building; a distinguished artist, William A. Mackay, painted the beautiful murals which adorn these walls. 


\section{THEODORE ROOSEVELT MEMORIAL}

We believe this Memorial justly reflects the majesty of the great State of New York, and is a fitting tribute to the great man whose memory it perpetuates.

It is the earnest prayer of our Board of Trustees that these magnificent walls may long enshrine the personality of that great leader of America - Theodore Roosevelt.

Acting on behalf of my co-Trustees, I now tender this Memorial to you as Governor of this State, with the sincere hope that the consummation of our task may have your approval. 


\section{ADDRESS BY \\ GOVERNOR HERBERT H. LEHMAN}

Mr. President, Mrs. Roosevelt, Mayor and Mrs. La Guardia, Mr. Kiernan, Members of the Board of Trustees of the Roosevelt Memorial, distinguished Guests, Ladies and Gentlemen: I welcome with pride the opportunity of paying a tribute to the memory of one of my most distinguished predecessors. It is fitting that the State of New York, through the gift of this Memorial, should pay a lasting tribute to a man who was a great Governor, a great President of the United States and a great American. The Memorial which we are dedicating today is an eloquent recognition of the debt which the State owes to one of its most illustrious sons-Theodore Roosevelt.

I feel a great satisfaction, too, in participating in these ceremonies with another great predecessor in the Governor's chair-he who now is President of the United States, Franklin D. Roosevelt. The interest in this undertaking which he displayed immediately on his inauguration as Governor in 1929 and which was continued throughout his administration, made possible the progressing of the work on this Memorial.

We are saddened by the absence of a man whose energy, enthusiasm, and vision over a period of many years were the inspiration and motivating force that carried the Roosevelt Memorial to completion. Professor Henry Fairfield Osborn, long President of the American Museum of Natural History and the first Chairman of this Roosevelt Memorial Commission, unfortunately was called to his eternal rest only a short time ago. He served the people of the State and the City of New York well, not only in the creation of this splendid Memorial, but as an educator, scientist, and civic leader. During the 


\section{THEODORE ROOSEVELT MEMORIAL}

many years of his useful service he wielded great influence in the life of our community.

He gave of himself without stint and without thought of self in the creation of this memorial and in the development of the cultural life of his country. I deem it a privilege to express, on behalf of the people of the State, very deep appreciation and thanks for his inspired leadership and service.

I also wish to express thanks to the trustees of the Roosevelt Memorial for their long and devoted service, the fruition of which is this splendid Memorial.

No brick and mortar, no shaft or monument is needed to keep ever fresh the warm affection and regard which Theodore Roosevelt is held in by the people of this state, and yet this magnificent building, dedicated to cultural use by the people, is a highly appropriate expression of the deep pride and love of the citizens of the Empire State for one of its great sons.

It will be a link in our great educational system for the training of youth. It is particularly fitting that it will be used by the youth of the city and state because Theodore Roosevelt was a lover of youth. Few men in our history have influenced the ideals of youth more deeply than he nor more greatly held youth's confidence and affection. He always was attracted to youth and youth was attracted to him and followed him loyally. He was outstandingly a man of moral and physical courage. With rare understanding he appreciated human values and he was bold in the application of the characteristics of youth to human problems. On the wall here there is inscribed the following words: "Only those are fit to live who do not fear to die and none are fit to die who have shrunk from the joy of living and the duty of life." That sentence, after all, well expressed his philosophy of life. He felt that to play the game of life courageously and boldly was always 
worth effort and sacrifice, and that no considerations of personal security or personal convenience justified men in shirking their responsibilities in order safely to sit on the side lines of life.

Rather did he feel it was wise to hitch his wagon to a star; to put his strength to the test in behalf of the weak, the oppressed, the exploited-even though he knew defeat was inevitable.

His fight against political and business corruption, against greed, against exploitation of the weak was by no means always successful. But with all the strength of his hatred of injustice he felt-and, of course, he was right beyond any question-that it is far better to have even a forlorn hope in a just cause than to seek security of person and position and representation through corruption, compromise or through inaction. He wrote, "It is hard to fail; but it is worse never to have tried to succeed. In this life we get nothing save by effort; far better it is to dare mighty things, to win glorious triumphs, even though checkered by failure, than to take rank with those poor spirits who neither enjoy much nor suffer much, because they live in the great twilight that knows neither victory nor defeat."

On the walls of this great hall of this building there are painted scenes depicting the accomplishments of a great President: acts of physical courage-undertakings which resounded to the glory and profit of our nation. The knowledge of these achievements will be handed down from generation to generation in our histories and in our text books. For all of them Theodore Roosevelt unquestionably deserves our sincere appreciation and admiration.

Yet to me the greatest contribution which he made to American life and to American ideals was the ceaseless and brave fight which he waged to arouse the conscience 
of the American people in behalf of clean government, honest business, and social justice. He knew, as all honest men in public life must know, that clean and honest government can prevail only if it has the support of an enlightened and militant public opinion. As Governor he wrote: " . . men in public life are what the men in private life make them. We must in the long run represent what is best and what is worst in you. You complain of bad government. It is ultimately the fault of the people themselves if it is bad. No American can shake off the burden. The public men must in the long run respond approximately to the effective desires of the people, to whom they go ultimately for power. . . . It is not the men in office who make public life. It is the men out of office who are the arbiters of our public life. It rests on every man in the city, on every man in the state and nation to make public life high."

These words, my friends, are no less true today than when Theodore Roosevelt penned them nearly forty years ago.

As President he wrote of dishonesty in business: "The 'business' which is hurt by the movement for honesty is the kind of business which, in the long run, it pays the country to have hurt . . but if it were true that to cut out rottenness from the body politic meant a momentary check to an unhealthy seeming prosperity, I would not for one moment hesitate to put the knife to the corruption." And when a friend of his wrote in protest against what he decried as an attack on business, he wrote:

"To me your regret is incomprehensible. You blame me for what I have done. To me it seems that I have the right to the fullest and heartiest support of every good man whose eyes are not blinded by unhappy surroundings, and who has in him a single trace of the fervor for 
righteousness and decency without which goodness tends to be an empty sham. If your soul does not rise up against corruption in politics and in business, why, then, naturally you are not in sympathy with me."

These words, my friends, were spoken in 1906. We dare not forget them in 1936.

Mr. Mayor, on behalf of the people of the State, I now take great pleasure in turning this building over to the City of New York, to be used for the benefit of the people of our commonwealth, and to serve as a tribute to one of the greatest of Americans. May it long remind this and succeeding generations of the courageous and passionate fight that Theodore Roosevelt waged for justice and righteousness, and for honesty, tolerance, and high public service. 


\section{ADDRESS BY MAYOR FIORELLO LA GUARDIA}

Mr. President, Governor Lehman, Ladies and Gentlemen: May I add to the tribute that has been paid to the memory of the late and lovable Henry Fairfield Osborn. New York City has lost one of its most distinguished and scholarly sons. The Institution of the American Museum of Natural History is a monument to his genius and energy. Everyone who came in contact with him in connection with the memorial we are dedicating today, caught the contagion of his enthusiasm. We all feel his presence at this very moment.

It seldom happens that a monument is erected to the memory of a patriot and statesman by his own contemporaries. It is a privilege for Americans who lived during the life of Theodore Roosevelt to leave to the next generation this testimonial of their great esteem, admiration and gratitude based on first hand knowledge of his work, his accomplishments and public service.

This monument is an expression of our appreciation for his great contribution to the cause of America, and a lasting, living inspiration to carry on his ideals and those great fundamental principles for which he fought.

The heroic proportions and the magnificence of this memorial are not only in keeping with the tribute he deserves, but are typical of Theodore Roosevelt's greatness, courage, breadth and vision.

I visited this Hall some months ago, and was awed by its vastness, emptiness, and the silence that prevailed. I was depressed rather than inspired. It is different todayalive with active men and women who are thinking of the past, studying the present, and planning the future of our country. So it should be. This Hall must not be 
shrouded in a sepulchral atmosphere. It must be devoted to public use, for gatherings and discussions. It must ever teem with humanity, typical of the activity, the energy, the dynamic life of the great Roosevelt.

Roosevelt first entered public life as a young Assemblyman when the political boss was in full power; when invisible government was at its peak. He did not like such a system. He had no illusions, and charted his course to restore the control of government to the people. He learned of corrupt political machines when he became a Police Commissioner of this city. He learned of the inefficiencies of Government as a soldier in the SpanishAmerican War. He knew the country through his travels and time spent in the far west. He spoke the language of the cowpuncher on the western plain and of the banker in the eastern city. He knew the miner who worked down in the earth and the poet who lived in the clouds. A true democrat in the finest sense of the word, never patronizing but ever companionable, he enjoyed the talk of the illiterate and loved the company of the classicist. He was not ashamed to have it known that he conferred and consulted with men of letters, of science, and even professors. Not all the intriguing, scheming and plotting of seasoned political bosses could keep him from the White House. It was his destiny and there he landed.

When Theodore Roosevelt entered the White House, he and no one else was President. He soon departed from established political custom and assumed open leadership in the legislation which followed. Any one of hundreds of the accomplishments of this great American would justify the perpetuation of his memory. His official life was so full and rich that a review in any one address is simply impossible. The history, the literature, the records, the press of his time are but the daily index of 
his busy life. Though extremely progressive for his time, he was a Fundamentalist in his belief and conviction in the American system of government. He never hesitated, wavered or faltered to defend that system. He ignored abuse and plunged forward. No one saw clearer and defended more convincingly the American system of government based upon three coordinate branches of government-the legislative, the excutive, and the judicial. He would not permit the Senate to become a court of justice; he would not permit the court to transform itself into a legislative body. Through his energetic action he endeavored to keep the three marching abreast, each in its own path. He knew what was judicial and he knew what was legislative. He knew what was legalistic and he knew what was scientific. When the interest of the country demanded the building of an inter-oceanic canal, he consulted the engineers and not the constitutional lawyers. The canal was built. There it is. When it was necessary for this country to assume leadership in world peace, he as President sent the invitation to the warring nations of Russia and Japan, and through sheer personality crystalized public opinion which forced the conference and ended hostilities. When industry entered into the machine age and it became necessary to provide an entirely new system of laws for the protection of life of workers, he consulted the legislative branch and obtained the necessary laws. When it was necessary to curb a greedy monopoly restraining trade he resorted to the courts. He took the constitution forward when time could not be taken back. He would not permit the constitution to be used as an instrument of oppression or as a justification for special privilege. When one branch of the government sought to prevent progress by infringing upon the prerogatives of another branch of government, he would rush in with a smashing, slashing attack. $\mathrm{He}$ 


\section{THEODORE ROOSEVELT MEMORIAL}

saw the necessity of keeping both the legislatures and the courts in their proper places.

His purpose and determination to prevent the encroachment of one branch of government on the sphere of the other was in keeping with the political philosophy of Abraham Lincoln. He was emphatic and concise on this subject. In a special message to Congress on December 8,1908 , he said:

"The legislators and executives are chosen to represent the people in enacting and administering the law. The judges are not chosen to represent the people in this sense. Their function is to interpret the laws, but they are to be blamed when they fail to recognize under a government like ours the deliberate judgment of the majority as to a matter of legitimate policy, when duly expressed by the legislature. For the courts to arrogate to themselves functions which properly belong to the legislative bodies is all wrong, and in the end works mischief."

On February 21, 1912, before the Ohio Constitutional Convention at Columbus, Theodore Roosevelt said :

"I believe in pure democracy. With Lincoln, I hold that 'this country, with its institutions, belongs to the people who inhabit it. Whenever they shall grow weary of the existing Government, they can exercise their Constitutional right of amending it.' * * * *

"I am emphatically a believer in constitutionalism, and because of this fact I no less emphatically protest against any theory that would make of the Constitution a means of thwarting instead of securing the absolute right of the people to rule themselves and to provide for their own social and industrial well-being.

"Lincoln so interpreted and administered the National Constitution. Buchanan attempted the reverse. ${ }^{*} * *$ It was Buchanan who treated the courts as a fetish, who protested against and condemned all criticism of the 
judges for unjust and unrighteous decisions, and upheld the Constitution as an instrument for the protection of privilege and of vested wrong."

That is as applicable now as then. Taking such a stand attracted as much abuse then as it does now. The next day, on February 22, 1912, commenting on these utterances, the New York Sun editorially said:

"We beg leave to remark that it is the most astonishing and, in view of healthy intelligence, the craziest proposal that ever emanated either from himself or from any other statesman since the organization of our government by law."

There were economic and industrial problems to be solved in his time, as we have today. Conditions created by changed industrial, transportation and agricultural systems required a new approach and imposed new functions upon government.

Speaking at Carnegie Hall, March 20, 1912, Colonel Roosevelt stated then what may well be the text today:

"When, as the result of years of education and debate, a majority of the people have decided upon a remedy for an evil from which they suffer, and have chosen a legislature and executive pledged to embody that remedy by law, and the law has been finally passed and approved, I regard it as monstrous that a bench of judges shall then say to the people 'you must begin all over again'."

It was this kind of vigorous, courageous defense of the Constitution which resulted in many necessary laws, attacked in State and Federal courts, finally finding a permanent place on the statute books of our states and country.

The question asked by Theodore Roosevelt in 1912 may well be asked today: "Are the American people fit to govern themselves, to rule themselves, to control themselves?" We say today, as he said then, that the answer 
THEODORE ROOSEVELT MEMORIAL

is "Yes". Because of his abiding faith in the American people he was not deterred by opposition, criticism, and abuse. Because of that faith, he gave his all to the American people. To Theodore Roosevelt and to his faith, this monument is erected.

Mr. Governor, on behalf of the City of New York I accept this monument and dedicate it to the public use.

Mr. A. Perry Osborn, I entrust it to the stewardship of the American Museum of Natural History. 


\section{ADDRESS BY \\ MR. A. PERRY OSBORN}

Mr. President, Governor Lehman, Mayor LaGuardia, Mr. Chairman, Ladies and Gentlemen: Seventeen years ago this January all the world mourned the death of Theodore Roosevelt. The American people were stunned by the loss of their leader and friend; they realized that a vital, driving force for good had come to an end.

During the years that have passed many people have kept faith with the high ideals and fundamental truths which he championed. Many have spoken and written about his life and his varied contributions to our lives. Many people and many groups have, in their own way, memorialized his life in thought, word and deed, as well as in tangible monuments. It was given to one man-a boyhood and life-long friend-to conceive an enduring and inspiring Memorial. He envisioned a Memorial building as part of the American Museum of Natural History in the City of New York, to be erected by the people of the State of New York, where Theodore Roosevelt was born, lived and died. This building should be simple in architecture, yet splendid and heroic in dimension; the building should possess warmth and color, and serve in ideal yet useful purpose, making its appeal to all men. Thus, the building should have the very characteristics of the man it memorialized. For this tireless seeker of knowledge, this fearless hunter and explorer in all parts of the earth, to whom the voice of nature was as familiar and appealing as the voice of humanity, a Memorial entrance to the Museum would suitably portray these unique attributes and interests. The entrance would be his gateway to the earth and its inhabitants, his portal to nature and her ways. 
Uniting the Memorial with an institution of worldwide learning would rightly emphasize the universality of the man, for his many attributes-leader, statesman, patriot, educator, author, explorer, naturalist and humanitarian-were built upon a character broad and deep and arose from a nature that was universal. Thus, the Memorial proposed would symbolize the outward characteristics, portray the various attributes, and above all emphasize the universality of this truly remarkable man.

Over the years this vision took form and when its appropriateness as well as its educational and spiritual value was appreciated, the people of our State approved and authorized the erection of the Memorial building and its location on the site proposed. Successive Governors-Governor Smith, Governor Roosevelt, Governor Lehman-State and City officials and successive State Legislatures, gave every cooperation to the Memorial Trustees charged with the responsibility of carrying out the undertaking. A creative architect, John Russell Pope, drew plans, sound builders erected the building, and true artists, painters and sculptors adorned it. The friend with the vision, Henry Fairfield Osborn, watched over it all with loving care. He gave many years of his life, and much of his strength, to the planning, completion and perfection of the work.

And now the building is completed and dedicated. Can we not believe that in this Memorial the spirit of Theodore Roosevelt is recreated, ready as always to lead our people along the strenuous, righteous and broad way of life?

Look about and you will observe that the first two floors serve as an entrance to the Museum, useful and adequate. The upper portions of the building contain 
study rooms, work rooms, and a lecture hall to serve educational purposes. We are now gathered in the Memorial Hall, which is so designed that it may be kept as a place apart from the day by day life of the Museum. That this Hall should be a place apart, and a place of reverence, was fundamental in the conception of the Memorial. Here people who come will find peace and quiet, and in the nobility of these surroundings will think of the man for whom this Memorial stands both as a tribute and as a symbol of his greatness. Here people will find help for their own lives and inspiration to serve humanity and country. Meetings of our citizens will be held in the Memorial for objects in which the great man himself was interested, and so broad were his interests that these meetings will take in the range of human activity.

What an appropriate, useful, beautiful and inspiring Memorial this is, an honor to all its creators as well as to the man it honors!

Mayor LaGuardia and Governor Lehman, on behalf of the President and Trustees of the American Museum of Natural History, I accept with gratitude and with full sense of our responsibilities the stewardship of the New York State Roosevelt Memorial. We pledge to you, Sirs, observance of the educational purposes for which this building was erected. Here we will welcome the youth of the State whom we are especially asked to remember. We pledge ourselves to regard the sacredness of this Memorial Hall. In our stewardship we will keep faith with the people of our State and will be true to the ideals of Theodore Roosevelt. 


\title{
THEODORE ROOSEVELT MEMORIAL
}

\section{Roland Hayes sings "The Battle Hymn of the Republic".}

\author{
THE BATTLE HYMN OF THE REPUBLIC
}

\section{Julia Ward Howe}

\section{6}

Mine eyes have seen the glory of the coming of the Lord:

$\mathrm{He}$ is trampling out the vintage where the grapes of wrath are stored;

He hath loosed the fateful lightning of His terrible swift sword:

His truth is marching on.

I have seen Him in the watch-fires of a hundred circling camps; They have builded Him an altar in the evening dews and damps;

I can read His righteous sentence by the dim and flaring lamps.

His day is marching on.

He has sounded forth the trumpet that shall never call retreat;

$\mathrm{He}$ is sifting out the hearts of men before His judgment-seat:

Oh! be swift, my soul, to answer Him! be jubilant, my feet!

Our God is marching on.

In the beauty of the lilies Christ was born across the sea, With a glory in $\mathrm{His}$ bosom that transfigures you and me: As $\mathrm{He}$ died to make men holy, let us die to make men free, While God is marching on.

VICE-CHAIRMAN KIERNAN: I now have the great pleasure of presenting a worthy son of an illustrious father, Colonel Theodore Roosevelt. 


\section{ADDRESS BY}

\section{HONORABLE THEODORE ROOSEVELT, JR.}

Mr. President, Governor Lehman, Mayor LaGuardia, Mr. Chairman, Ladies and Gentlemen: I have listened with keen attention to the various gentlemen who preceded me giving their interpretation of my father's contribution to State and Nation. Others will speak of his scientific achievements. I should like and I am going to speak of some of the intimate sides of his love for nature.

At home I have a battered volume of "Wood's Natural History" in which his name is scrawled in a boyish hand. It was his first nature book. While reading it his artistic sense evidently overcame him, for the picture of the elephant is extra-illustrated with a platoon of little figures of the single line school which are chopping at the elephant's back and legs with what look like knives and axes. In other convenient places he has drawn strange animals that I am sure, in later life, he would have characterized as "nature fakes".

His love of nature began when he was very young. By this time he was only ten or twelve and he was really actively interested. His father, another Theodore Roosevelt, helped and encouraged him in every way. There is a family story telling how his elder sister objected when she found he was keeping dead mice in the ice box. He is supposed to have remarked solemnly on hearing this that she was obstructing the course of science.

It was at about this time that he founded the family museum. The case that housed it is still in the gun-room at Sagamore; and when I was little, there still remained some meritorious stuffed birds in a glass bell to bear witness to departed glories. A few of the specimens of this museum of his served not only as the foundation of the 


\section{THEODORE ROOSEVELT MEMORIAL}

museum that we all had as children, but were also in turn the foundation of the museum which my own children later founded. I also have the large blank book in which he catalogued his collections. It is a very neat, very accurate piece of work.

When father went to college he was a real naturalist. His early notes on birds were published. In fact he once told me that he almost decided to become a professional naturalist. Even if not his vocation, natural history was always his greatly loved avocation. Though he could not carry a tune, by hard work he learned to recognize the bird songs with astonishing accuracy.

Here in this museum where we are today there are collections of bird skins made by him sixty years ago, with Fred Osborn, brother of Professor Fairfield Osborn. Very early he became fast friends with distinguished members of the American Museum staff. One of my first memories is of walking up Madison Avenue with Professor Osborn and father, while the little Osborn children, of whom Perry, who has just spoken, was one, and I, scampered ahead. Dr. Frank Chapman was one of his closest friends and used to be constantly at the house. $\mathrm{He}$ had a large natural history and hunting library to which he added continually. He subscribed to Dr. Chapman's magazine "Bird Lore" and "The Auk," and read them from cover to cover. Another close friend of his was Dr. C. Hart Merriam.

I remember him telling me of a time when Hart Merriam came west to the ranch in Dakota to collect. Father asked the foreman of the ranch to fit him out with a jungle team of horses. In 24 hours Dr. Merriam returned with a broken wagon and his equipment scattered. He said the horses had bolted. Father called in Merrifield, the foreman, and asked why he had given Dr. Merriam a team of runaway horses. Merrifield replied, 
"Them wasn't a runaway team. That team was plum gentle. The off horse, why to be sure he had run away, but there was lots of times he had not run away, and the nigh horse, why he had never been druv but once."

When father was in the west on hunting trips he used to catch and skin small rodents for the museum. Once a very rare shrew skin was drying on the end of a log. Someone put the log on the fire and the skin was burned. Father never forgot this and spoke to me about it half a dozen times. Another time the cow punchers, who had been watching with interest what he did, asked him if there was "any money in skinning mice".

He taught my brother Kermit and me to skin small animals when we were very small ourselves. The first bird we practiced on was a robin. Then I attempted a heron. Its neck defeated me and the result was a terrifying creature of nightmare aspect.

He used to take us children for long walks through the woods and tell us about the birds and animals. Mother was the authority on flowers. He particularly enjoyed the winter when the tracks on the snow told volumes of stories.

The first book he ever gave me was "Homes without Hands" by Wood. It was given to him by his father in 1868. He gave it to me when I attained the lofty pinnacle of education where I could pick out the letter " $\mathrm{H}$ ".

When he became a great figure in national and international affairs, his interest in natural history never lagged, as many of you here today can testify. He became the driving force behind conservation and the protection of wild life, for the naturalist is always a conservationist. $\mathrm{He}$ founded the Boone and Crockett Club and was one of the pillars of the Audubon Society.

Once, when he was President, he burst in on one of his Cabinet meetings, saying, "Gentlemen, do you know 


\section{THEODORE ROOSEVELT MEMORIAL}

what happened this morning?" The Cabinet shuddered in anticipation of some earth-shaking calamity. My father continued, "While I was walking in the garden just now I saw a chestnut-sided warbler-and this is only February."

Naturalists of all kinds and all nationalities came to the house, from German ichthyologists to Swedish herpetologists. A great friend of his was Lord Gray, the British statesman, who was also a naturalist. During my father's visit to England after his return from Africa the two of them went to the New Forest to study the birds. Gray described the trip in a charming essay called "Recreation," and here in the museum Dr. Chapman has prepared a memorial of this incident. If my father were here today, he would be very proud of this building. He would appreciate the Boy Scouts, because he was a very firm believer in the Boy Scout movement.

We realize particularly the depth of the affection for him by the American people, when we see so many distinguished gentlemen here; gentlemen holding the highest places in the land, paying tribute to his memory, in spite of the fact that most of them opposed him during his life.

We in the family believe that my father would be very proud of this Memorial we are dedicating today. It deals with natural history, of which he was so fond, and will benefit the people of the country to whose service he dedicated his life. We wish to express our appreciation to all of you who have contributed so signally to it. We wish particularly to express our appreciation for the efforts of Professor Osborn, whose recent death is deeply felt by all.

Vice-Chairman Kiernan: Colonel Roosevelt, we all greatly appreciated hearing the interesting and per- 
THEODORE ROOSEVELT MEMORIAL

sonal incidents of your father's life, with which we were not familiar.

Ladies and Gentlemen: I now take pleasure in introducing a man who had a devoted relationship with Theodore Roosevelt up to the time of his death, and who is the head of the Roosevelt Memorial AssociationHonorable James R. Garfield. 


\section{ADDRESS BY \\ HONORABLE JAMES R. GARFIELD}

Mr. Chairman, Mr. President, Mr. Mayor, Honored Guests: I wish to express to you on behalf of the Association of which I am president our very great appreciation of what you have said regarding Theodore Roosevelt.

Theodore Roosevelt once said: "The same homely virtues apply in managing the life of a nation as in managing an individual's life. All the statesman needs to do is to exercise common sense and stick as close to the decalogue and the golden rule as imperfect human nature will permit . . . The man is a poor citizen who does not do his best to see that the affairs of his country, both as regards the country's attitude to other nations, and as regards the country's dealings with matters vital to its own citizens within its limits, are managed along the same lines-the old simple lines of honesty, courage and common sense."

These words express the rule of conduct which he strove to follow.

The story of his life has become one of the vital forces in our Nation's life. It appeals to the imagination, giving inspiration for high endeavor and noble purpose. His thoroughness of preparation in many fields of activity, his intimate knowledge of the conditions under which men worked in shops and mines, on farms and railroads, gave him an accurate, sympathetic understanding of human problems. He made history the handmaiden of progress, not a series of dry facts but a living record of experience which could be used as a guide to determine the wise course to pursue. His genius was the use of that knowledge for attainable ends. He recognized that the experience of mankind could not safely be ignored. It 
was an aid, not a stumbling block, to steady and permanent progress. His leadership was based upon the faith men had in his character. He had an infinite capacity for comradeship. His recognition of the good that was in all sorts and conditions of men earned the friendship of many in every walk of life.

The great purposes of his life were to afford men more equal chance with their fellows to make the most out of life and to improve the conditions under which people work and live. He saw clearly the burdens and evils of life, but did not allow himself to be overwhelmed by them, knowing that in the long run they could be overcome by righteous conduct. He strove for social and economic justice, not theoretical but practical, pointing the way for the attainment of measures in State and Nation which would make it possible to care for illness, accident, death, old age, unemployment.

In business and political fields his purpose was to clear the highway of commerce from unfair, unconscionable obstructions, to protect and safeguard those who obeyed law and dealt fairly with the public and their competitors, and to enforce the penalties of law against those who pursued the opposite course. He invariably studied and gave expression to both sides of any great problem and urged each side to take its share of burden and to do its share of work. He never divided men into classes, such as employer and employee, rich and poor, nor suggested different rules of conduct for such classes. He drew the dividing line, as he expressed it, "perpendicularly, not horizontally," "up and down and not across." On the one side were all decent, law-abiding men, whether rich or poor, labor leader or capitalist; on the other side all lawbreakers, all undesirables of whatsoever walk or work in life. Corporations were classified by a like line-a corporation was attacked, not because it 
was big, but because it gained its strength by illegal means or misused powers. All corporations that were obedient to law were safeguarded and upheld.

In his address at the dedication of the McKinley Memorial occurred a striking example of his habit of fair statement. After referring to the support honest men should receive, he spoke as follows:

"From the standpoint of our material prosperity there is only one thing as important as the discouragement of a spirit of envy and hostility toward honest business men, toward honest men of means; this is the discouragement of dishonest busness men.

"Wait a moment; I don't want you to applaud this part unless you are willing to applaud also the part I read first, to which you listened in silence. I want you to understand that I will stand just as straight for the rights of the honest man who wins his fortune by honest methods as $I$ will stand against the dishonest man who wins a fortune by dishonest methods. And I challenge the right to your support in one attitude just as much as in the other. I am glad you applauded when you did, but I want you to go back now and applaud the other statement. I will read a little of it over again. Every manifestation of ignorant envy and hostility toward honest men who acquire wealth by honest means should be crushed at the outset by the weight of a sensible public opinion."

While believing in the ultimate sound judgment of the American people he was not deluded into any dream that a democracy was free from grave dangers. He realized that the "people's rule" would degenerate into either plutocracy or mob rule, unless the great majority of the individual citizens were intelligent, decent, alert and honest. He knew that political institutions could be kept free only when they were not controlled by special interests, whether those interests were political or economic. 


\section{THEODORE ROOSEVELT MEMORIAL}

He recognized "That obedience to law is the foundation to liberty", and that "Where law ends, tyranny begins". He accepted citizenship as a high duty, not a cheap right. Patriotism for him meant work and sacrifice, the giving of life, if necessary. He had contempt and stern reprimand for those who played with patriotic sentiment or who spent their exertions in mere clamor for the people's rights while the people's interests were being neglected or destroyed. He appealed to young men because his was a spirit of enthusiastic youth, unfailing energy. The thousands of boys and girls who visit his birthplace learn to appreciate his home life, to understand the scope of his interests, and gain inspiration to strive for the ideals for which he strove.

This Memorial symbolizes another side of his life, natural history, out-of-doors, recreation. They were as much an essential part of his life as was his serious work. They gave him needed rest, kept up his vigor of mind and body. But he made his days of recreation means for some useful end, some contribution to the store of scientific knowledge or general culture.

He appealed to the older generation because of the universality of his knowledge, the soundness of his judgment, his will and courage to speak and act for the general good.

He brought out the best that was in his associates, and had in a remarkable degree the ability to work with men, never hesitating to give credit to those who earned it. In developing his policies of conservation, natural resources, country life, education, he sought the assistance of those who, as he believed, were qualified to aid in carrying forward those policies.

This habit of team work resulted in continuity of purpose and effectiveness of effort in the solution of any problem. 
His intimate acquaintance with men of other countries-such as Bryce and Jusserand-made it easy to discuss international questions informally and thoroughlythus avoiding possible misunderstandings.

He gained the respect and admiration of the people of other countries because he kept our foreign relations upon a basis of mutual fulfillment of obligations.

It is good that such a man has lived. The highest tribute to his memory will be for us to hand down to coming generations the story of his life.

I think it appropriate to read two verses from the poem of Kipling written immediately after Theodore Roosevelt's death :

The heat of his spirit

Struck warm through all lands,

For he loved such as showed

'Emselves men of their hands;

In love, as in hate,

Paying home to the last

But our world is none the kinder

Now Great Heart has passed!

Hard schooled by long power,

Yet most humble of mind

Where aught that he was

Might advantage mankind.

Leal servant, loved master,

Rare comrade, sure guide

$\mathrm{Oh}$, our world is none the safer

Now Great Heart hath died! 
GOVERNOR LeHMAN: Mr. Chairman, before we adjourn, may I move that on behalf of this great assemblage a telegram be sent to Mrs. Theodore Roosevelt, Sr., conveying to her our greetings, our high regard both for her husband and for her, and the expression of our sincere hope that she will be restored to full health at an early date.

(Motion unanimously carried).

\section{Benediction by Chancellor Charles W. Flint}

God of our fathers, we thank Thee for the memory of a great American citizen who fought a good fight, finished his course, and kept the faith. May a double portion of the spirit which inspired this servant of God and of his fellowmen rest upon us and upon all succeeding generations in this land of the free, home of the brave, in the Name of the Father, the Son, and the Holy Ghost. Amen. 


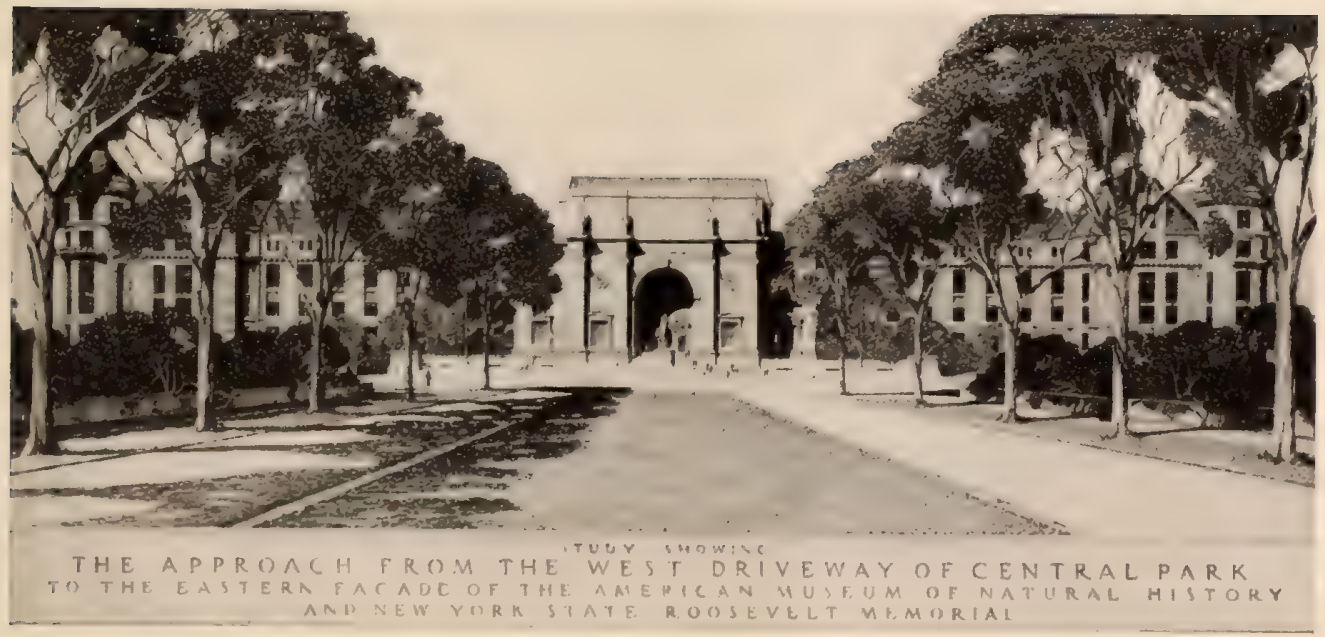

Study showing the Proposed Approach from the West Driveway of Central Park to the Eastern Facade of the New York State Roosevelt Memorial 



\title{
LIST OF EXECUTIVES AND EAGLE SCOUTS
}

\author{
From the "Boy Scouts of America"
}

\author{
Participating in the Dedication Exercises
}

\section{EXECUTIVES}

Dr. James E. West Albert L. Pellaton

\section{Council}

Manhattan

"6

Brooklyn

"6

66

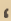

\section{Queens}

16
16
4
16

Bronx
$" 6$
$" 6$
$" 6$

Staten Island

i6 66

c6 16

Nassau County

$\begin{array}{ll}\text { "6 } & 6 \\ 4 & 6 \\ 46 & 6 \\ 16 & 6\end{array}$

Mohican

Rockland County

Siwanoy

$$
\text { "s }
$$

Yonkers

Suffolk County

Bronx Valley
Dr. E. D. Partridge

F. Howard Covey

Lawrence E. Abt

\section{State}

New York

a 6

16 cs

6 6

a a

b) 45

c6 c6

646

64

68

6 .6

16 a

660

$46 \quad 6$

If 16

a) 46

a 66

68 (16

c6 6

(6) 66

a6 66

66

68 (6)

co

a)

a 6

$66 \quad 68$

$16 \quad 66$

16 6

6
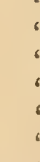

"

Dr. Lorne W. Barclay Kenneth B. Spear 


\section{THEODORE ROOSEVELT MEMORIAL}

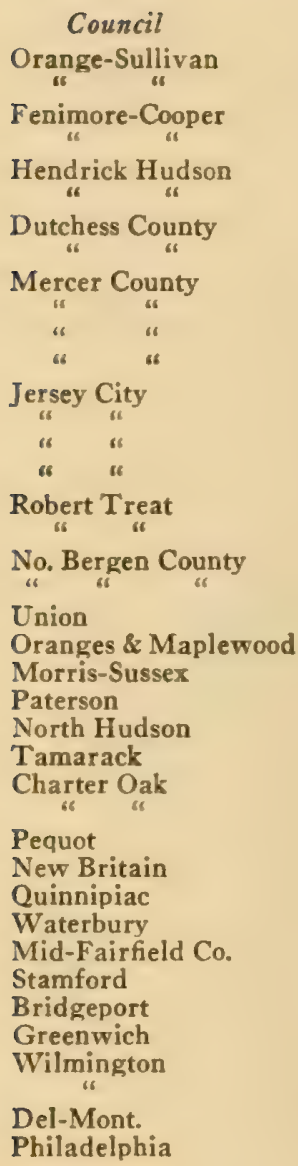

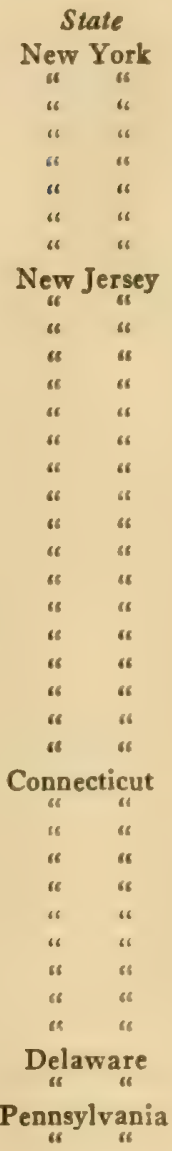

\section{Eagle Scouts}

Frederick L. Stutz, Troop 5

Harry Rising, Quarters 67 U. S. M. A.

Ben Herrnann, Troop 17

Norman Scott, Troop 20

Robert Dever, Troop 42

George Heinner, Troop 1

Myron Gurnee, Troop 22

Francis Schoenberger, Troop 7

Phil Feenan, Troop 35

James R. Reed, Troop 12

Raymond Critchlow, Troop 12

Arthur S. Jensen, Troop 20

Charles Huneke, Troop 25

Leon Griffin, Jr., Troop 2

William Benz, Troop 19

Harold L. Wickholm, Troop 12

Frank Schleicher, Troop 50

George Freeman, Troop 45

Wesley, Philo, Troop 96

Bernard Schmitter, Troop 96

Phillip C. Wells, Troop 52

Bill Demant, Troop 1

George Anderson, Troop 13

Richard Harry, Troop 13

John K. Barker, 'Troop 10

Charles C. Compton, Troop 3

Charles DuQuetto, Troop 18

Thomas A. Hubbs, Troop 118

Vernon Fadden, Troop 5

Arthur S. Day, Troop 4

Edgar Bird, Troop 12

Chester Spiers, Troop 7

Lester Lyan, Troop 22

Perry Polk, Troop 19

Frederick Porter, Troon 19

Howard Stanley Peterson, Troop 67

Lawrence Pond, Troop 19

Warren W. Grier, Jr., Troop 12

Edward Hayes, Troop 1

William Hawley, Troop 20 



